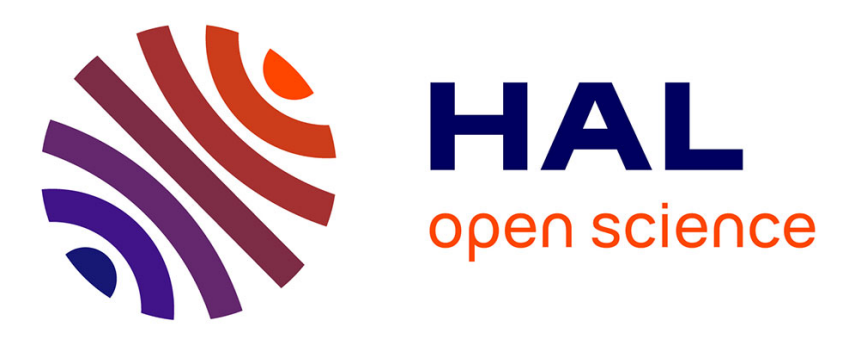

\title{
Giving recipient communities a greater head start and including productive species boosts early resistance to invasion
}

Manon C.M. Hess, Elise Buisson, Hugo Fontès, Leo Bacon, Florent Sabatier, François Mesléard

\section{To cite this version:}

Manon C.M. Hess, Elise Buisson, Hugo Fontès, Leo Bacon, Florent Sabatier, et al.. Giving recipient communities a greater head start and including productive species boosts early resistance to invasion. Applied Vegetation Science, 2020, 23 (3), pp.340-352. 10.1111/avsc.12502 . hal-02981931

\section{HAL Id: hal-02981931 \\ https://hal.science/hal-02981931}

Submitted on 28 Oct 2020

HAL is a multi-disciplinary open access archive for the deposit and dissemination of scientific research documents, whether they are published or not. The documents may come from teaching and research institutions in France or abroad, or from public or private research centers.
L'archive ouverte pluridisciplinaire $\mathbf{H A L}$, est destinée au dépôt et à la diffusion de documents scientifiques de niveau recherche, publiés ou non, émanant des établissements d'enseignement et de recherche français ou étrangers, des laboratoires publics ou privés. 


\title{
Giving recipient communities a greater head start and including productive species boosts early resistance to invasion
}

\section{Time advance and productivity reduce invasion}

\author{
Manon Célia Morgane Hess ${ }^{1,2,3}$, Elise Buisson ${ }^{2}$, Hugo Fontes ${ }^{3}$, Léo Bacon ${ }^{4}$,
}

\author{
Florent Sabatier ${ }^{3}$, François Mesléard ${ }^{2,3}$
}

${ }^{1}$ NGE-GUINTOLI, Saint-Etienne du Grès, Parc d'activités de Laurade - BP22, 13156 Tarascon Cedex, France

${ }^{2}$ Institut Méditerranéen de Biodiversité et d'Ecologie marine et continentale (IMBE), Avignon Université, UMR CNRS IRD Aix Marseille Université, IUT Site Agroparc, BP 61207, 84911 Avignon Cedex 09, France

${ }^{3}$ Institut de recherche pour la conservation des zones humides méditerranéennes Tour du Valat, Le Sambuc, 13200 Arles, France

${ }^{4}$ Office Français de la Biodiversité, Unité Avifaune Migratrice, Le Sambuc, 13200 Arles, France

Correspondence

Manon Hess, Institut Méditerranéen de Biodiversité et d'Ecologie marine et continentale, Avignon Université, France

Email: hess@tourduvalat.org 


\section{Abstract}

Questions: Giving a time advance to restored native plant species has recently been considered a promising way to improve their persistence and reduce invasion success (i.e. through priority effects). However, little is known about the influence of the elapsed time between seeding and invasion and its interaction with other characteristics such as species composition and density, despite the fact that it could substantially help developing effective management strategies.

Methods: In a pot experiment, we simulated invasion by three major invasive species (Ambrosia artemisiifolia, Bothriochloa barbinodis, and Cortaderia selloana) in soil covered with recipient communities differing in species composition (one, three or nine species), density (700 or 2,778 seeds $/ \mathrm{m}^{2}$ ), and time advance (established one or five months previously). We assessed early invasion success by measuring seedling emergence and survival over six months.

Results: Early invasion success was mainly explained by recipient community's time advance and composition (or their interaction), while density had limited influence. Polycultures (three or nine species) showed generally greater invasion resistance, most likely due to high aboveground biomass essentially produced by two species. Species composition interacted with time advance in two ways: (1) Bothriochloa barbinodis seedling emergence was impacted by composition only in communities having five months of advance, suggesting that the contribution of species composition to invasion resistance varies according to the age of the community, and (2) Ambrosia artemisiifolia and Cortaderia selloana survival was affected by time advance in polycultures only, which produced much more biomass than monocultures, implying that a greater head start provides a competitive advantage only if it allows a sufficient increase in biomass production.

Conclusions: Implementing revegetation as soon as site clearance work is over, as well as establishing productive native species may help reduce invasion success. How much of an advantage recipient community time advance represents depends on biomass production.

Keywords: assembly, biomass, biotic resistance, coexistence, composition, density, historical contingencies, invasive species, multistate models, priority effects, restoration, revegetation 


\section{1| Introduction}

The alarming rate of biodiversity loss worldwide has been attributed particularly to the constantly increasing spread of invasive species (Mollot et al. 2017; Seebens et al. 2017), highlighting the importance of designing effective and environment-friendly methods of invasive species control. The current expansion of anthropologically disturbed areas promotes plant invasions (Facon et al. 2006; Hobbs \& Huenneke 1992), with disturbances like vegetation clearance increasing resource availability and decreasing competition from resident species (Davis et al. 2000). Active reestablishment of native plant cover after a disturbance is increasingly being advocated as a method of reducing invasive plant species colonization and spread locally (Byun \& Lee 2017; Larson et al. 2013; Middleton et al. 2010). The idea is that re-established communities exhibit a certain resistance to invasions (biotic resistance; Levine et al. 2004), mainly through resource competition at the neighborhood scale (Goldstein \& Suding 2014; Levine et al. 2004). It has also been suggested that it may be more effective to combat invasive species at the seedling stage, since: (1) the seedling stage is considered one of the most vulnerable stages in the life cycle of a plant (Kitajima \& Fenner 2000); and (2) initial seedling establishment largely determines subsequent population success (Albrecht \& McCarthy 2009; Kitajima \& Fenner 2000).

Consequently, designing native plant communities capable of quickly acquiring robust invasion resistance is a fundamental step in limiting invasive species establishment. Recently, giving a time advance to the native species over invasives has been suggested as a way to improve native species persistence and limit invasive species colonization through priority effects (Delory, Weidlich, Kunz et al. 2019; Firn et al. 2010; Grman \& Suding 2010; Hess, Mesléard, Buisson 2019; Vaughn \& Young 2015; Wolf \& Young 2016). Priority effects, by which early-arriving species affect the establishment, survival, growth or reproduction of later colonizers (Helsen et al. 2016), are considered to be mainly induced by resource preemption (Fukami 2015), but can also arise from alterations of biotic (e.g. soil microorganisms) and abiotic (e.g. allelochemicals, nutrient dynamics) components of the environment (Corbin \& D'Antonio 2012; Mangla \& Callaway 2008). Prior establishment of native species has been shown to strongly decrease invasion success. For instance, Grman and Suding (2010) found a ten-fold reduction in invasive species biomass when native species were planted five weeks earlier. Delory, Weidlich, Kunz et al. (2019) showed that in the exotic species Senecio inaequidens biomass was 96\% to 99\% lower when arriving with a 21-day delay over native species. However, little attention has been paid to the influence of elapsed time between seeding and invasion in interaction with community characteristics (Helsen et al. 2016; Hess, Mesléard, Buisson 2019; Orloff et al. 2013; von Gillhaussen et al. 2014).

Timing of species arrival can have substantial effects on community assembly (Ejrnaes et al. 2006; Harper 1961; Kardol et al. 2013; Körner et al. 2008; Ross \& Harper 1972; Sagar \& Harper 1960). Longer time intervals between arrival events are expected to result in greater asymmetry in plant size and stronger priority effects (Kardol et al. 2013; Wilsey et al. 2015), because early-arriving species have time to use available resources more completely. Therefore, extending the time advance of natives over invasives should lead to increased invasion resistance. Since plant species vary in size and biomass production, the benefit of increasing time advance could however depend on species composition. Also, increasing the density of resident individuals in a community (i.e. the number of individuals per surface unit) may also increase priority effects and reduce the recruitment of invasive species (Goldberg et al. 2001; Orloff et al. 2013; Yannelli et al. 2017, 2018), because establishing more individuals is expected to enhance resource acquisition, thereby reducing the resources available for invading species (Gerhardt \& Collinge 2007). However, increasing sowing density may only be efficient in the very early stages because biomass production stabilizes over time (i.e. density-dependent effects; (Burton et al. 2006; Carter \& Blair 2012; Crawley 2007; Nemec et al. 2013; von Gillhaussen et al. 2014). 
Invasive species management strategies could be substantially improved by a better understanding of how early invasion resistance is influenced by the time advance given to native species and its interaction with species composition and individuals' density, which are three parameters easy to manipulate. In a greenhouse experiment, we investigated how the elapsed time between seeding and invasion (hereafter 'time advance'; one or five months) in interaction with species composition (one, three or nine species) and density of individuals (700 or 2,778 seeds $/ \mathrm{m}^{2}$ ) influenced the early establishment success of three invasive species in Europe: Ambrosia artemisiifolia, Bothriochloa barbinodis and Cortaderia selloana. Early establishment success was monitored by recording seedling emergence and survival over six months.

\section{2| Methods}

\section{1| Species selection}

While many studies assess the response of a single invader (Byun et al. 2013; Byun \& Lee 2017; Dukes 2002; Firn et al. 2010), this does not allow for the detection of varying responses from invasive species (Emery 2007). Here, therefore, we monitored early establishment success of three species known to invade disturbed areas in Europe (Domenech \& Vila 2008; Fried 2010; Ozaslan et al. 2016) and disperse by seed (Allred 2003; Bassett \& Crompton 1975; Fried 2010; Lambrinos 2002): common ragweed (Ambrosia artemisiifolia L.), cane bluestem (Bothriochloa barbinodis (Lag.) Herter) and pampas grass (Cortaderia selloana (Schult. \& Schult.f.) Asch \& Graebn.).

The common ragweed (Ambrosia artemisiifolia L., Asteraceae) is an annual opportunistic weed introduced from North America more than a century ago (Heckel 1906). Thanks to its large ecological amplitude (Leskovsek et al. 2012; Onen et al. 2017) and high seed production (up to 18,650 seeds in France; Fumanal 2007), the common ragweed can successfully invade disturbed areas such as road sides, riverbanks, wastelands as well as cultivated fields (Lavoie et al. 2007; Simard \& Benoit 2010).

The cane bluestem (Bothriochloa barbinodis (Lag.) Herter, Poaceae) is a perennial warm-season C4-grass growing in upright clumps 60-120 cm tall (De Wet 1968; Koshi et al. 1977) native to the southern USA and Central and South America (Vega 2000). Only recently observed in Europe (1970s in southern France as Bothriochloa imperatoides (Hack.) Herter; Auriault 1976), it spreads fast along roadsides, railways and vineyards in large parts of France (Fried 2014; Verloove \& Sánchez Gullón 2012) and could become a serious invader (Fried 2010).

The pampas grass (Cortaderia selloana (Schult. \& Schult.f.) Asch. \& Graebn., Poaceae) is a perennial C4-grass introduced from South America into Europe and widely used as an ornamental landscape plant that can be up to $4 \mathrm{~m}$ in height and $3.5 \mathrm{~m}$ in diameter (Bacchetta et al. 2010; Bossard et al. 2000; Domenech \& Vila 2008). The small, wind-dispersed seeds (i.e. 106 seeds per mature plant; Domenech \& Vila 2008; Lambrinos 2002) are able to rapidly germinate under a wide range of ecological conditions (Domenech \& Vila 2007) and form dense monospecific stands (Bossard et al. 2000; Lambrinos 2002).

For each invasive species, we collected seeds from at least ten individuals from three mature populations in southeastern France (Supplementary material, Table S3.1). Seeds from Ambrosia artemisiifolia were initially cold-stratified to break dormancy and optimize germination (Bazzaz 1970). Seeds were placed between two cotton layers soaked in distilled water in a hermetically sealed plastic box covered with light-tight aluminum and refrigerated at $4^{\circ} \mathrm{C}$ for six weeks (Bae et al. 2017). Under favorable conditions, Cortaderia selloana and Bothriochloa barbinodis are able to rapidly reach high germination rates without cold stratification (Abbott \& Roundy 2003; Bacchetta et al. 2010; Costas-Lippmann 1979), and their seeds were therefore not cold-stratified. 
Before starting the experiment, we assessed the germination capacity of the three invasive species by placing 120 seeds in Petri dishes on cotton soaked in distilled water. The Petri dishes were placed in a growth chamber (Hotcold-GL: 12K lux; P-Selecta, Barcelona, Spain) and incubated at alternating temperatures $\left(15 / 25^{\circ} \mathrm{C}\right)$ with a photoperiod of $12 \mathrm{hr} / 12 \mathrm{hr}$ for one month. The highest temperate occurred within the 12-hr light period. Seedling emergence was monitored every three days until no seedling emergence was recorded. Seedlings were removed as they germinated. The results of these preliminary germination tests were used to adjust the number of seeds from each invader sown in the experiment, so as to ensure at least nine viable seeds in each pot (Supplementary material, Table S3.1).

To compose our recipient native communities, we selected nine perennial plant species widely used to revegetate roadsides in France: Achillea millefolium L., Dactylis glomerata L., Lolium perenne L., Lotus corniculatus L., Onobrychis viciifolia Scop., Plantago lanceolata L., Poterium sanguisorba L., Schedonorus arundinaceus (Schreb.) Dumort., and Trifolium repens L.. Commercially available seeds were obtained from ZYGENE (Charols, France). Species nomenclature follows TAXREF v13.0 (Gargominy et al. 2019).

\section{2| Study site and infrastructure}

This experiment was carried over one year (late September 2017 until late September 2018) at the Research Institute of Tour du Valat, France $\left(43^{\circ} 30^{\prime}\right.$ N, $4^{\circ} 40^{\prime}$ E, $1 \mathrm{~m}$ elevation). The climate at the site is Mediterranean, characterized by warm to hot, dry summers and mild, wet winters, with high interannual variability (Lionello et al. 2006). Air temperature and precipitation data were measured continuously at a meteorological station located close to the experimental site (Figure S3.1Erreur! Source du renvoi introuvable.). Plant communities were established in square plastic pots (with a width of $30.5 \mathrm{~cm}$ at the top and $25 \mathrm{~cm}$ at the bottom, $27 \mathrm{~cm}$ deep) containing from bottom to top: (1) a 27-cm diameter polyester textile filter (® Diatex textile (DIATEX, Saint Genis Laval, France) with 50-70 $\mu \mathrm{m}$ mesh size to prevent loss of substrate), (2) a polystyrene bloc (width $20 \mathrm{~cm}, 10 \mathrm{~cm}$ deep) allowing water to flow at the sides, (3) a substrate mixture consisting of 30 vol\% vermiculite (® Projar; Projar Group, Valencia, Spain) 2.6 $\mathrm{kg} / \mathrm{m}^{3}$ ), and $70 \mathrm{vol} \%$ commercial organic and fertile topsoil (® Geolia; Leroy Merlin, Nîmes, France; Figure S3.2). All pots were kept in a greenhouse with ${ }^{\circledR}$ Diatex mesh walls and roof (600-500 $\mu \mathrm{m}$ mesh size) to ensure that climate conditions were similar to outside conditions and to prevent seed dispersal from the surrounding area. In addition to the ambient precipitation, all pots received equal amounts of demineralized water through sprinklers placed equidistantly. The amount of additional water was adjusted according to weather conditions so as to ensure conditions favorable to germination and plant development.

\section{3| Experimental design}

The experiment was designed to simulate situations where seeds of invasive plant species (Ambrosia artemisiifolia, Bothriochloa barbinodis and Cortaderia selloana) reach soil covered with native plant species re-established on bare soil after a disturbance or restoration actions involving vegetation clearing.

In each pot, we established recipient communities showing three different species compositions: one, three or nine species (hereafter called respectively '1-sp', '3-sp' and '9-sp' communities; Table 3.1). Lolium perenne was selected for the 1-sp treatment because it is usually the dominant species in commercial seed mixtures (Arienzo et al. 2004). The 3-sp treatment included Lolium perenne, Plantago lanceolata and Trifolium repens. The 9-sp treatment included all the species cited above (Table 3.1). Hereafter, 'monocultures' refers to 1-sp communities, and 'polycultures' refers to 3-sp and 9-sp communities. We tested two levels of species density, sowing either 700 or 2,778 recipient community 
Table 3.1 Species composition and density applied per species of recipient communities differing in density (LowD = low density, HighD = high density) and species composition (1-sp = 1 species, 3-sp $=3$ species, 9 -sp $=9$ species .

\begin{tabular}{|c|c|c|c|c|c|c|c|}
\hline \multirow{3}{*}{$\begin{array}{l}\text { Functional } \\
\text { group }\end{array}$} & \multirow{3}{*}{ Species } & \multicolumn{6}{|c|}{$\begin{array}{c}\text { Density } \\
\text { (no. seeds/pot) }\end{array}$} \\
\hline & & \multicolumn{3}{|c|}{ LowD } & \multicolumn{3}{|c|}{ HighD } \\
\hline & & $1-\mathrm{sp}$ & $3-\mathrm{sp}$ & 9-sp & $1-\mathrm{sp}$ & 3 -sp & $9-\mathrm{sp}$ \\
\hline \multirow{3}{*}{ Grasses } & Lolium perenne & 63 & 22 & 9 & 250 & 82 & 30 \\
\hline & Dactylis glomerata & - & - & 4 & - & - & 20 \\
\hline & Schedonorus arundinaceus & - & - & 6 & - & - & 30 \\
\hline \multirow{3}{*}{$\begin{array}{l}\text { Leguminous } \\
\text { forbs }\end{array}$} & Trifolium repens & - & 20 & 6 & - & 84 & 30 \\
\hline & Lotus corniculatus & - & - & 6 & - & - & 25 \\
\hline & Onobrychis viciifolia & - & - & 9 & - & - & 30 \\
\hline \multirow{3}{*}{$\begin{array}{l}\text { Non- } \\
\text { leguminous } \\
\text { forbs }\end{array}$} & Plantago lanceolata & - & 21 & 8 & - & 84 & 30 \\
\hline & Poterium sanguisorba & - & - & 9 & - & - & 30 \\
\hline & Achillea millefolium & - & - & 6 & - & - & 25 \\
\hline
\end{tabular}

seeds $/ \mathrm{m}^{2}$ (63 or 235 seeds/pot, hereafter called respectively 'LowD' and 'HighD' communities; Table 3.1 , Figure 3.1). Recipient community seeds were sown either 175 or 29 days (hereafter called respectively '5-month' and '1-month' communities) before invasive species seeds. 
Sowing densities were chosen in line with the densities commonly applied in roadside revegetation. Native

were

fixed

either $3.5 \mathrm{~cm}$

$1.5 \mathrm{~cm}$

apart and to ensure invasive individuals surrounded native neighbors $3.3)$.

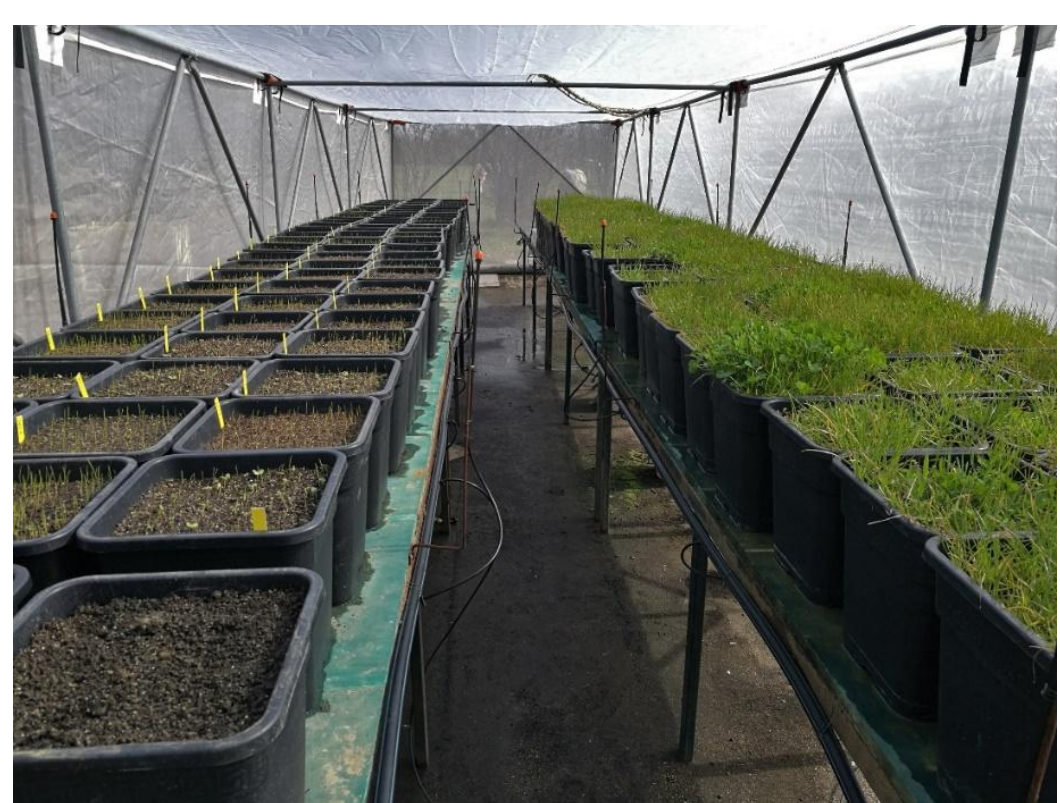

Figure 3.1 Recipient communities at the time of invasive species introduction (left: 1-month and right: 5-month communities). species seeds

allocated to

positions,

(LowD) or

(HighD)

chosen so as

that all

species

were

by the same

species

(Figures 3.2, 
A

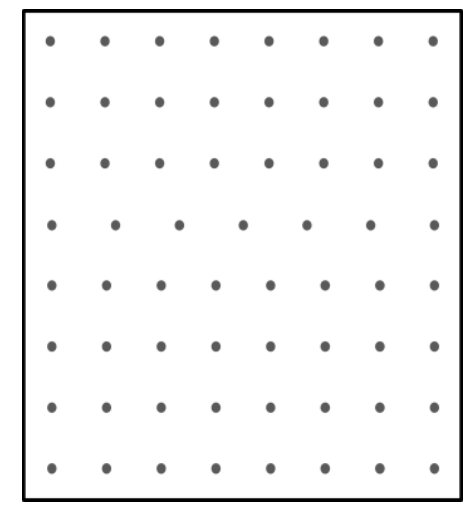

B

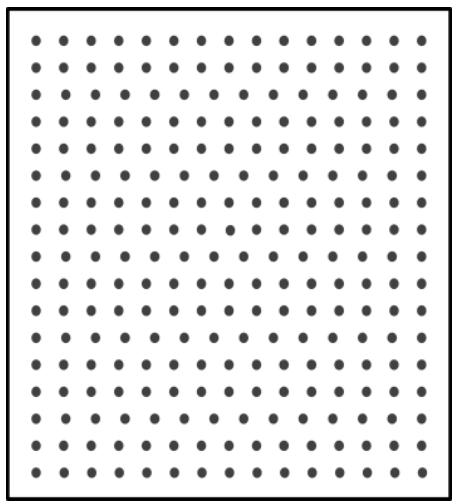

C

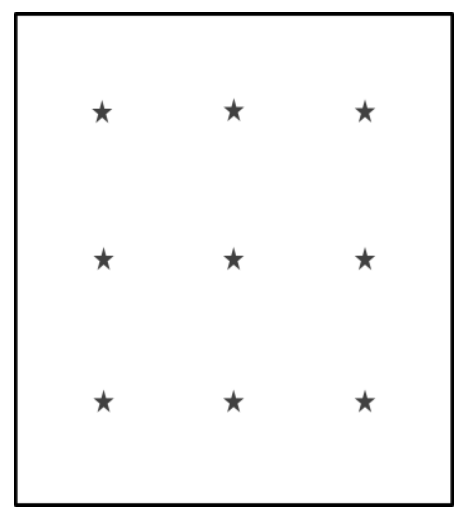

Figure 3.2 Pot spatial arrangement of (A) Low density recipient communities (63 seeds/pot), (B) High density recipient communities (235 seeds/pot) and (C) invasive species seeds.

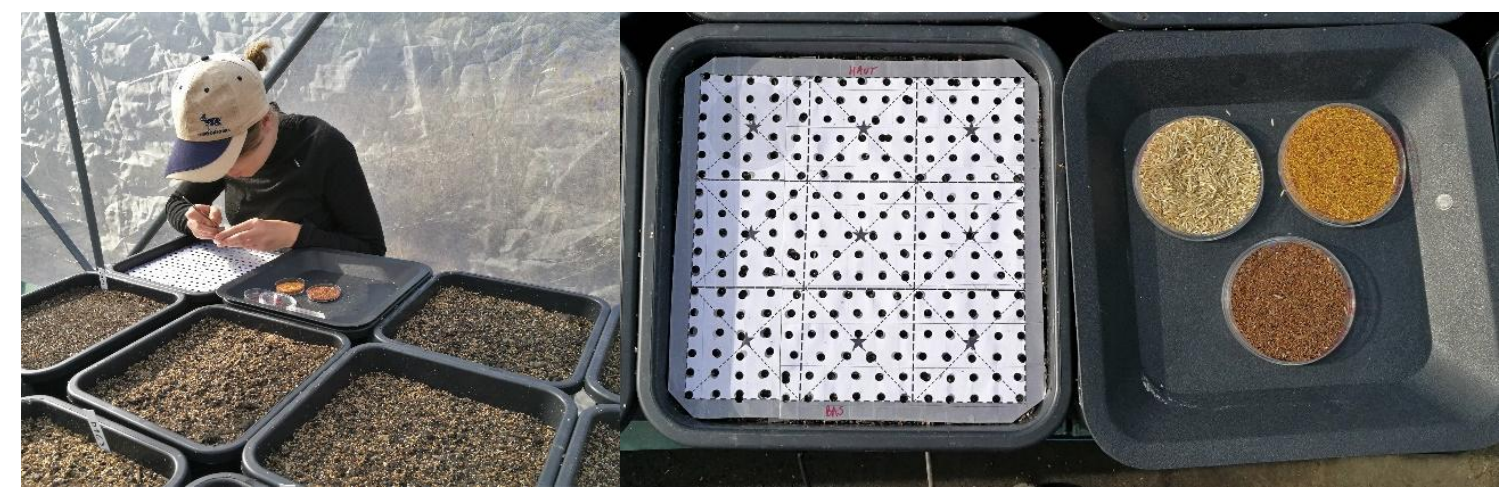

Figure 3.3 Seed sowing was realized using cardboard with holes (each hole corresponding to a seed) as to ensure a fixed spatial arrangement of the recipient communities.

Before the invasive species were introduced, any ungerminated native species seeds were replaced, to ensure the intended density of seedlings. On March 22, 2018, seeds from one invasive species were sown in each pot at nine fixed positions $8 \mathrm{~cm}$ apart. In order to reduce the bias related to the intrinsic germination capacity of the harvested invasive species seeds, we adjusted the number of seeds introduced at each position from two to five (Supplementary material, Table S3.1) based on the preliminary germination tests described above (Supplementary material, Table S3.1). If several seedlings emerged from the same position, only the seedling at the most advanced development stage was kept. Seedling emergence rate was therefore considered to be $100 \%$ when at least one individual emerged at each position.

For each invasive species, there were four replicates of each recipient community type (i.e. each combination of recipient species time advance $\times$ composition $\times$ density) and four control pots with bare soil, totaling 156 pots. Pot distribution followed a randomized design and was randomized six times during the experiment to take account of microclimate effects. 


\section{4| Data collection}

The aim of this experiment was to understand the ways by which characteristics of the recipient communities (i.e. time advance, species composition and density) influenced early invasion success. Hence, in addition to monitoring early establishment success of the invasive species, we collected data on the recipient communities' characteristics susceptible to mediate early invasion resistance i.e. biomass production, vegetation cover, and soil nutrient content. We did not seek to evaluate the impact of invasive species on recipient communities.

Early establishment success of invasive species was assessed by monitoring seedling emergence and survival of each invasive plant individual each week for the first six weeks and then every two weeks until the end of the experiment. Seedlings were considered to have emerged when any part was visible. We considered the invasion resistance of the recipient community to have increased when there was a reduction in probability of invasive species establishment (seedling emergence or survival). The aboveground biomass of each native species of the recipient community was measured either: (1) once all invasive individuals had died within a pot, even before the end of the experiment; or (2) at the end of the experiment, even if individual invasives remained alive. For each pot, aboveground biomass was collected $1 \mathrm{~cm}$ above ground level, sorted by species and dried at $80^{\circ} \mathrm{C}$ for $48 \mathrm{hr}$ until weighed. Total below-ground biomass (native and invasive species roots) was measured at the end of the experiment for six randomly selected pots per recipient community type. For this purpose, one eighth of the pot soil volume was randomly withdrawn. Roots were isolated, washed and sieved with a $250-\mu \mathrm{m}$ mesh, dried for $48 \mathrm{hr}$ at $80^{\circ} \mathrm{C}$ and weighed. We then estimated dry root weight per pot by multiplying the dried sample weight by 8 .

To estimate vegetation cover at the time of invasive species seed introduction, digital images of the pots were acquired for computed image analysis via a Nikon D80 (Nikon Corporation, Tokyo, Japan) digital camera with a 10.2 megapixel CDD sensor. The camera was mounted on a 1.4-m high fixed camera stand with the lens facing exactly perpendicular to the ground, where the pots were placed successively.

Soil resource availability influences competition intensity (Craine \& Dybzinski 2013), as well as the importance of priority effects (Kardol et al. 2013). We therefore analyzed organic carbon, nitrogen, nitrates, ammonium and available phosphorus on soil samples collected from each pot at the time of invasive species seed introduction. For this purpose, 72 soil cores of $10 \mathrm{~mm}$ diameter $\times 100 \mathrm{~mm}$ deep were collected for each recipient community type (six per pot), pooled and air-dried for $48 \mathrm{hr}$ at $40^{\circ} \mathrm{C}$ and sieved $(<2 \mathrm{~mm})$ to remove roots and rocks. Samples were analyzed for: (1) organic carbon by sulfochromic oxidation (NF ISO 14234, 1998); (2) total nitrogen by the modified Kjeldhal method (NF ISO 11261, 1995); (3) nitrate $\mathrm{NO}_{3}{ }^{-}$and ammonium $\mathrm{NH}_{4}{ }^{+}$(NF ISO 14256-2, 2007); and (4) available phosphorus $\mathrm{P}_{2} \mathrm{O}_{5}$ by the Dyer method (NF X31-160, 1999). All soil parameters were determined according to the standard French method AFNOR (Afnor 1994) or standard international method ISO. Analyses were conducted by an accredited soil analysis laboratory following standard protocols (Teyssier 2020).

\subsection{Data analyses}

\section{Modelling invasive species seedling emergence and survival}

We used a multistate capture-recapture modeling framework (Lebreton \& Cefe 2002) to estimate the seedling emergence and daily plant survival probabilities of introduced invasive individuals. In this study, multistate capture-recapture modeling was preferable to simple logistic regressions, as it allowed the different transition probabilities (seedling emergence, plant survival) to be integrated within a common 
framework. Capture (introduction of invasive species seeds) and recapture (subsequent visits) events were defined according to the experimental monitoring protocol. Monitoring intervals were specified in days to take into account unequal time intervals. We considered each individual as being in one of three states: seed (S), plant (P) and dead (D). Seed state means that no part of the emerged seedling was visible. Plant state means that any part of the seedling was visible and alive. Plants were considered dead when no green tissue remained. We examined the additive effects of time advance (time), species composition (comp) and density (den) and their interactions on the probability of seedling emergence (transition from seed to plant) and daily plant survival (transition from plant to dead state) of the three invasive species (Supplementary material S3.I). Our controlled conditions eliminated the possibility of individuals being missed during monitoring, so detection probability should be $100 \%$. Therefore, our models can be considered as 'known-fate' models, with no goodness-of-fit tests required (Cooch \& White 2019).

Model selection and parameter estimation were performed for each invasive species using the program ESURGE (which stands for multiEvent SURvival Generalized Estimation; Choquet et al. 2009). E-SURGE is a program for fitting multistate/multi-event models to capture-recapture (CR) data. Multistate models are survival models that can integrate state-dependent survival and transition probabilities among states. A state may be described as a categorical individual covariate that can change over time (e.g. seed and plant states).

Transitions may have a different meaning depending on the state definition (in our case probability of seedling emergence and survival). Our initial model was built to cover all the effects we intended to test:

\section{$\psi_{\text {time } \times \text { comp } \times \text { den }}, \varphi_{\text {time } \times \text { comp } \times \text { den }}$}

and modeled the probabilities of seedling emergence $(\psi)$ and survival $(\varphi)$. It incorporated the effects of time advance, species composition and density of the recipient community.

We followed a step-down approach proposed by Lebreton et al. (2009) for model selection, focusing first on seedling emergence probabilities and then on survival probabilities. The model selection was based on the Akaike information criterion corrected for overdispersion and small sample size (QAICc). We examined the effect of density, species composition and time advance by comparing QAICc scores, removing one effect at a time. We estimated a 95\% confidence interval (CI) for each parameter. Survival probabilities were daily estimates. A generic model description and the steps in the model selection procedure are provided in Supplementary material S3.I and S3.II.

\section{Total aboveground and belowground biomass of recipient communities}

We analyzed differences in final total aboveground and below- ground biomass depending on recipient community type using Kruskal-Wallis rank sum tests. When the type of community had a significant impact on biomass, a post-hoc Dunn's test was performed ('dunn.test' package; Dinno 2015). Analyses were performed via the $\mathrm{R}$ ver. 3.4.3 statistical platform ( $\mathrm{R}$ Core Team, R Foundation for Statistical Computing, Vienna, Austria). P-values lower than 0.05 were considered as statistically significant.

\section{Recipient vegetation cover}

We applied the image analysis method described by Stewart et al. (2007) to estimate percentage of vegetation cover in the pots, using consecutively Adobe 'Photoshop' software ver. 2015.0.1 (Adobe Systems, San Jose, CA, USA) and GIMP ver. 2.10.8 (GNU Image Manipulation Program, Groton, MA, USA) image processing software. Photoshop was used to select color and create the two masks separating vegetation (colored black) from ground (colored white). GIMP was then used to count the number of 
black and white pixels. The percentage of vegetation cover was obtained by dividing the number of black (vegetation) pixels by the total number of pixels in the image. We analyzed differences in vegetation cover depending on recipient community type using Kruskal-Wallis rank sum tests. When the type of community had a significant impact on vegetation cover, a post-hoc Dunn's test was performed ('dunn.test' package; Dinno 2015). Analyses were performed via the R ver. 3.4.3 statistical platform. Pvalues lower than 0.05 were considered as statistically significant.

\section{Soil analyses}

We analyzed differences both in total organic matter, carbon and nitrogen content, and in nitrate, ammonium and phosphorus content: (1) between soil containing 5-month and 1-month communities; and (2) between soil containing LowD and HighD communities, using a Wilcoxon-Mann-Whitney test. We also analyzed differences between soil with 1-sp, 3-sp and 9-sp communities, using a Kruskal-Wallis rank sum test. Analyses were performed via the R ver. 3.4.3 statistical platform. P-values lower than 0.05 were considered as statistically significant.

\section{3| Results}

\section{1| Invasive species seedling emergence}

The probability of seedling emergence (hereafter 'seedling emergence') was best explained by: (1) time advance for A. artemisiifolia and C. selloana; and (2) the interaction between species composition and time advance for B. barbinodis (Supplementary material S3.II). Ambrosia artemisiifolia and C. selloana showed lower seedling emergence in 5-month communities than in 1-month communities (Figure $3.4 A, C)$. While A. artemisiifolia seedling emergence was higher in the control than in communities

(Figure 3.4A), C. selloana seedling emergence tended to be similar or lower in the control than in communities (Figure 3.4C). Seedling emergence of B. barbinodis was similar in control, 1-month communities and 5-month monocultures, and was lower in 5-month polycultures (Figure 3.4B).

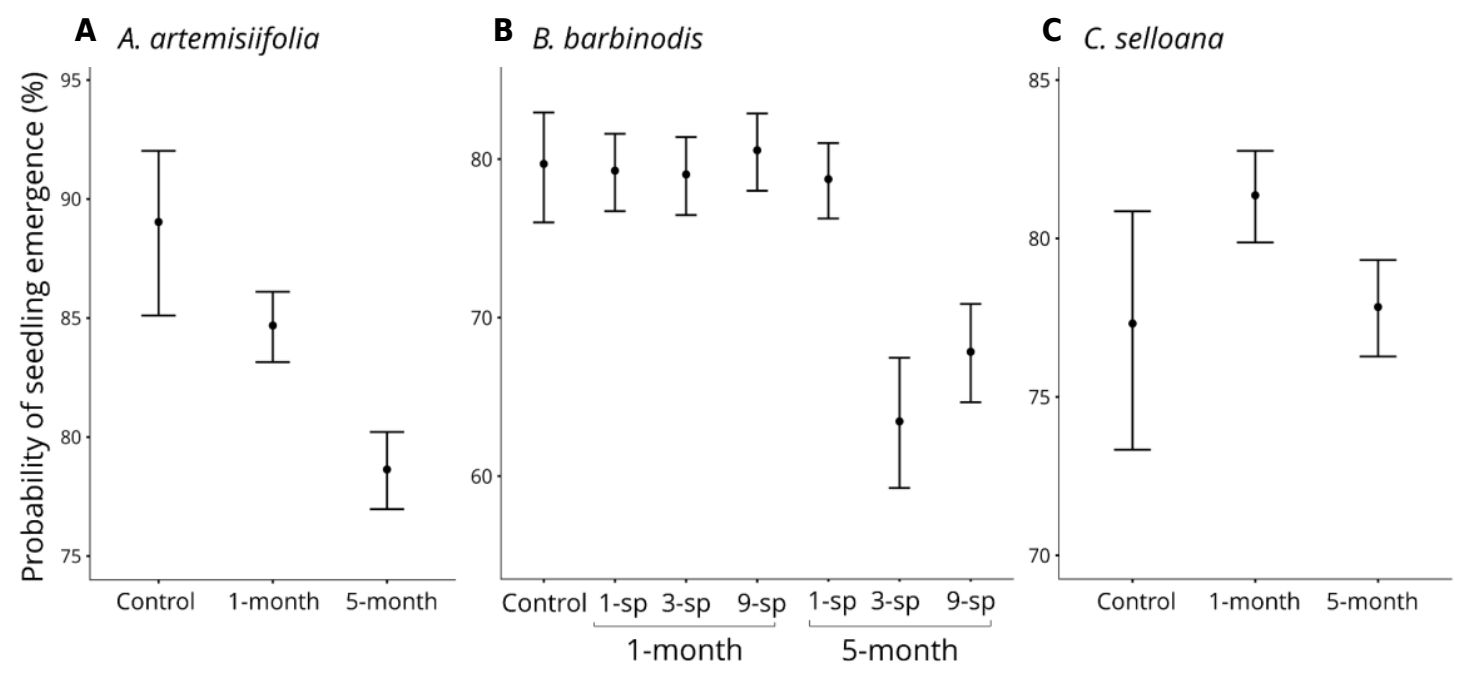

Figure 3.4 Probability of seedling emergence (model estimates; percentage $\pm 95 \% \mathrm{Cl}$ ) of the invasive species: (A) Ambrosia artemisiifolia ( $\mathrm{n}_{\text {tot }}=432$ ); (B) Bothriochloa barbinodis $\left(\mathrm{n}_{\text {tot }}=432\right)$; and (C) Cortaderia selloana $\left(n_{\text {tot }}=432\right)$, depending on recipient community on recipient community type: time advance over invasive species (one month or five months), species composition (1-sp = one species, 3$\mathrm{sp}=$ three species, 9 -sp = nine species), and density (LowD = low density, HighD = high density). Control refers to bare soil. 


\section{2| Invasive species survival}

The daily probability of survival (hereafter 'survival') was best explained by: (1) the interaction between density, species composition and time advance for A. artemisiifolia; (2) species composition for $B$. barbinodis; and (3) the interaction between species composition and time advance for $C$. selloana (Supplementary material S3.II). Survival was not (A. artemisiifolia and C. selloana; Figure 3.5A,C) or only slightly (B. barbinodis; Figure 3.5B) lower in monocultures than in control. All species survival was lower in polycultures than in control and monocultures (Figure 3.5). Survival of A. artemisiifolia and $C$. selloana was lower in 5-month polycultures than in 1-month polycultures and control (Figure 3.5A,C). A. artemisiifolia also showed lower survival in HighD than in LowD 1-month polycultures.
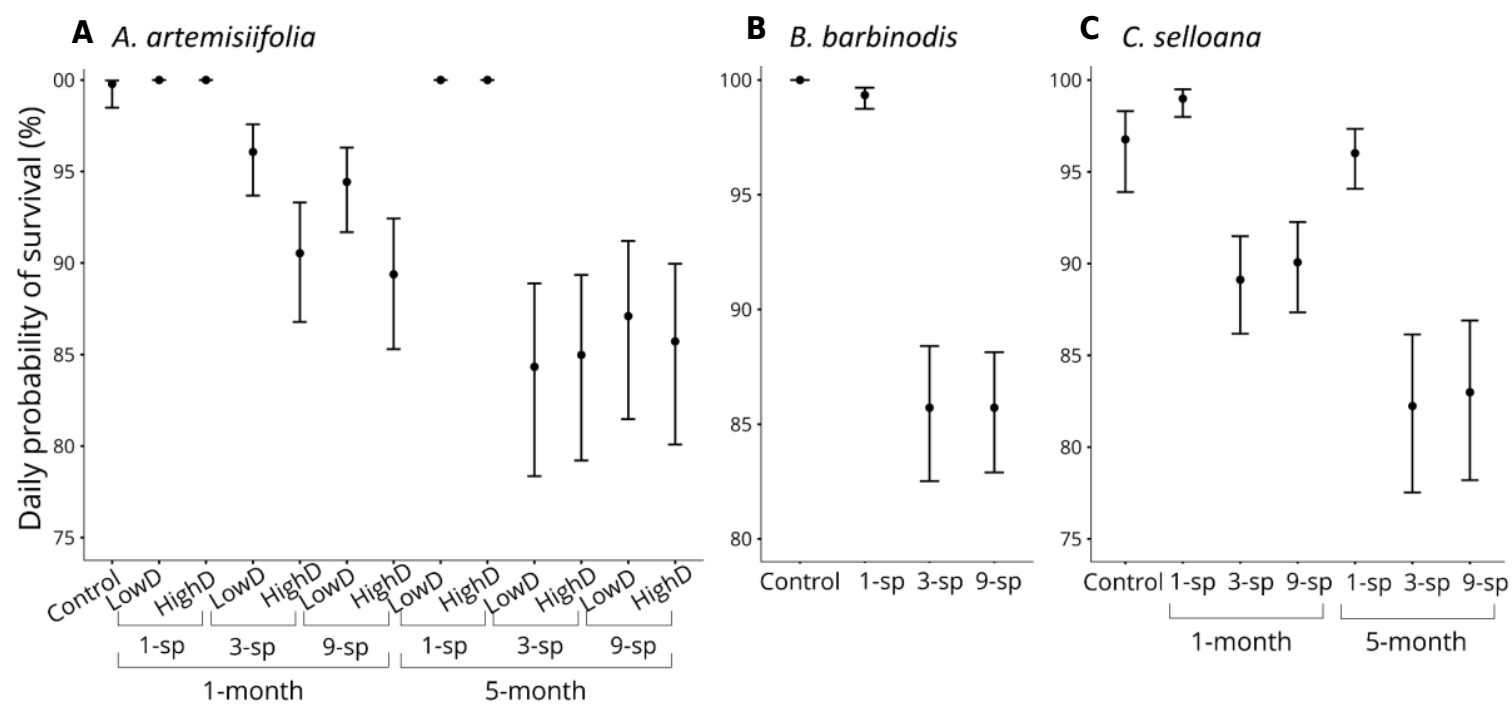

Figure 3.5 Daily probability of survival (model estimates; percentage $\pm 95 \% \mathrm{Cl}$ ) of the invasive species: (A) Ambrosia artemisiifolia $\left(\mathrm{n}_{\mathrm{tot}}=389\right)$; (B) Bothriochloa barbinodis $\left(\mathrm{n}_{\mathrm{tot}}=336\right)$ and $(\mathbf{C})$ Cortaderia selloana $\left(n_{\text {tot }}=368\right.$ ) depending on recipient community type: time advance over invasive species (one month or five months), species composition (1-sp = one species, 3 -sp = three species, 9 -sp $=$ nine species), and density (LowD = low density, HighD = high density). Control refers to bare soil.

\section{3| Total aboveground and belowground biomass of recipient communities}

Recipient community type significantly impacted the final total above-ground biomass of the recipient community (Kruskal-Wallis $\square^{2}=7.6, \mathrm{df}=11, \mathrm{p}<0.001$ ). Final total aboveground biomass was significantly lower in monocultures than in polycultures (post-hoc Dunn's test, $\mathrm{p}<0.01$; Figure 3.6), regardless of time advance and density. We found no significant difference between 3-sp and 9-sp communities (post-hoc Dunn's test, p>0.05; Figure 3.6). Trifolium repens largely dominated 3-sp communities, representing on average $76.4 \pm 8.2 \%$ of the total biomass, while L. perenne and P. lanceolata only represented $9.1 \pm 5.3$ and $2.8 \pm 1.1 \%$ (Figure 3.6). Lotus corniculatus dominated 9-sp communities, representing on average $61.3 \pm 10.5 \%$ of the total biomass, followed by T. repens $(16.7 \pm 6.6 \%)$ and D. glomerata $(5.9 \pm 2.0 \%$; Figure 3.6). The cumulative aboveground biomass of other species represented less than $5 \%$ of total aboveground biomass. No clear pattern was detected for final total belowground biomass (Supplementary material, Figure S3.3). 


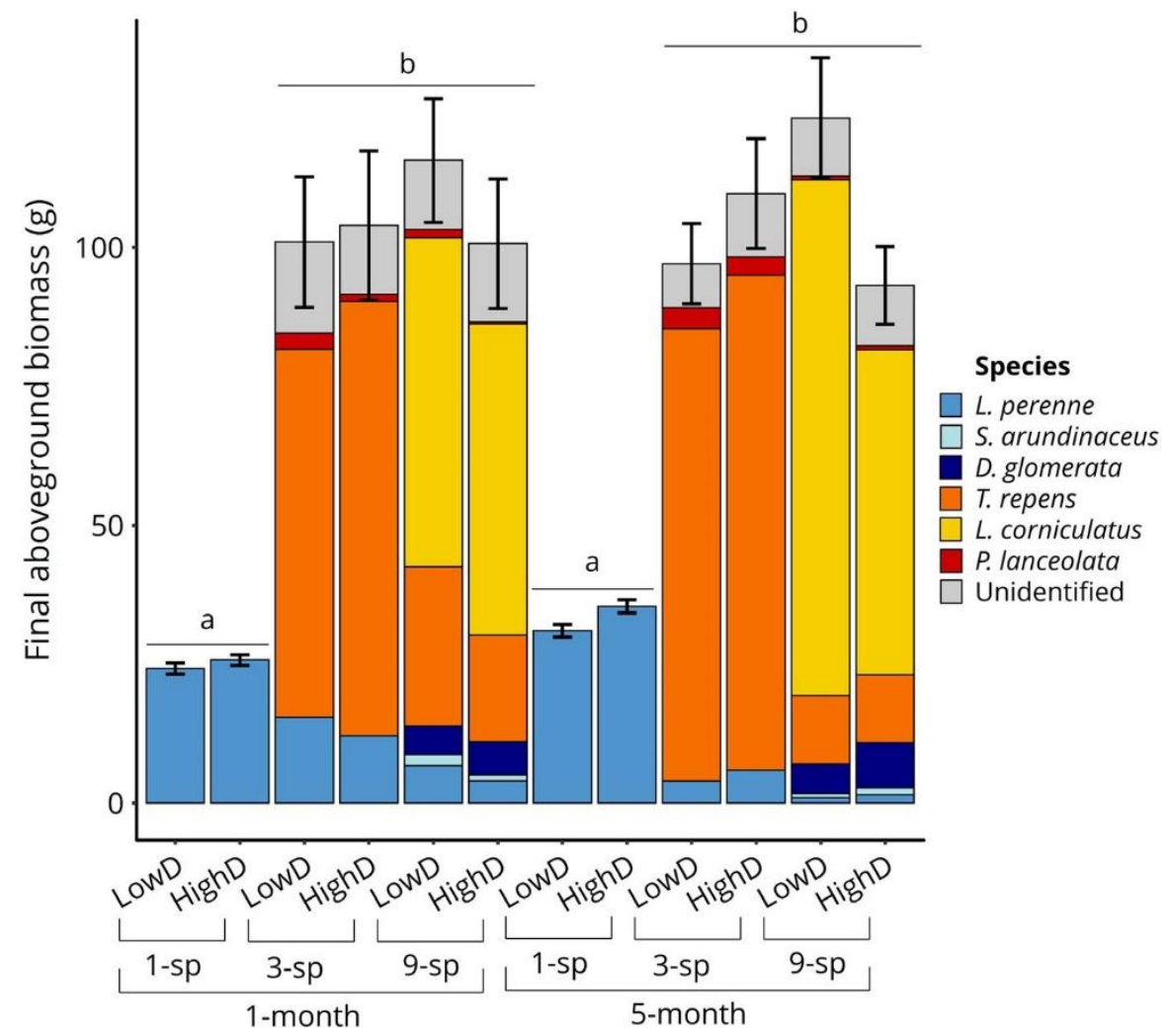

Figure 3.6 Final aboveground biomass of the community (mean $\pm S E, n=12$ ) classed by species, depending on recipient community type: time advance over invasive species (1 month or five months), species composition (1-sp = one species, $3-s p=$ three species, 9 -sp = nine species), and density (LowD = low density, HighD = high density). Values below $0.1 \mathrm{~g}$ are not represented, therefore Achillea millefolium, Onobrychis viciifolia, and Poterium sanguisorba are not shown. Letters $(a, b)$ distinguish total biomass means that are significantly different according to a post-hoc Dunn's test $(\alpha=0.05)$. 


\section{4| Recipient vegetation cover}

Recipient community type significantly impacted vegetation cover percentage at the time of invasive species introduction (Kruskal-Wallis $\square^{2}=127.07$, df=11, $<<0.001$ ). We found no statistical difference between 5-month communities, whatever the density or species composition (post-hoc Dunn's test, p >0.05; Supplementary material, Figure S3.4). 5-month communities had significantly higher vegetation cover than 1-month communities $(81.7 \pm 5.9 \%$ and $3.9 \pm 2.6$ respectively, post-hoc Dunn's test, $\mathrm{p}<0.05$; Supplementary material, Figure S3.4). In 1-month communities, increasing density significantly increased vegetation cover for each species composition (post-hoc Dunn's test, $\mathrm{p}<0.05$ ). Species composition did not impacted vegetation cover in 1-month communities so that no statistical difference was found between 1-month LowD communities ( $p>0.05$ ), nor between 1-month HighD communities (p>0.05; Supplementary material, Figure S3.4).

\section{5| Soil analyses}

Control soil was fertile (total nitrogen $=3.54 \mathrm{~g} / \mathrm{kg}$, nitrate $\mathrm{NO}_{3}{ }^{-}=0.092 \mathrm{~g} / \mathrm{kg}$, ammonium $\mathrm{NH}_{4}{ }^{+}=0.0446$ $\mathrm{g} / \mathrm{kg}$, available phosphorus $\mathrm{P}_{2} \mathrm{O}_{5}=0.273 \mathrm{~g} / \mathrm{kg}$ ) and had a high total organic matter content $(5.1 \%$; Supplementary material, Table S3.2). Total nitrogen, $\mathrm{NO}_{3}{ }^{-}, \mathrm{NH}_{4}{ }^{+}$and $\mathrm{P}_{2} \mathrm{O}_{5}$ contents were higher in control soil than in soil supporting recipient communities (Supplementary material, Table S3.2). We found no statistical difference in any measured soil parameter between soil supporting (1) LowD and HighD communities, nor (2) 1-sp, 3-sp and 9-sp communities ( $\mathrm{p}>0.05$; Supplementary material, Table S3.2). Soil supporting 5-month communities showed no difference in similar contents of total organic matter, carbon and nitrogen contents $(\mathrm{p}>0.05)$, and lower $\mathrm{NO}_{3}{ }^{-}(\mathrm{p}=0.005), \mathrm{NH}_{4}{ }^{+}(\mathrm{p}=0.005)$ and $\mathrm{P}_{2} \mathrm{O}_{5}$ $(\mathrm{p}=0.002)$ contents than soil supporting 1-month communities (Supplementary material, Table S3.2).

\section{4| Discussion}

Overall in this experiment, establishing a recipient community negatively impacted invasive species early establishment success (Figures 3.3, 3.4; Supplementary material, Figures S3.5, S3.6), supporting revegetation as a relevant tool to limit invasions (Byun \& Lee 2017; Larson et al. 2013; Middleton et al. 2010). Responses varied depending on the characteristics of the recipient communities and on the invasive species.

\section{1| Time advance mainly determined invasive species seedling emergence}

On its own, the time advance given to the recipient community mainly explained variations in seedling emergence of $A$. artemisiifolia and $C$. selloana, which tended to decrease with increasing time advance (Figure $3.4 A, C$ ). Germination is regulated by environmental components, mainly temperature, light, water (Koller \& Kozlowski 1972), and soil nitrate concentration (Pons 1989). Seeds can detect the presence of neighboring plants early on, in particular by perceiving (1) spectral changes in the light environment resulting from the presence of a canopy (Batlla et al. 2000), or (2) low nitrate availability resulting from nitrate preemption by plants (Pons 1989). Thus, the decrease in seedling emergence observed with increasing recipient community time advance (Figure 3.4A,C) may be related to both phenomena, since (1) vegetation percentage cover was much higher in 5-month than in 1-month communities (Supplementary material, Figure S3.4), and (2) significantly lower soil nitrate content was found for 5-month than for 1-month communities at the time invasive species were introduced (Supplementary material, Table S3.2).

Responses differed between invasive species. While seedling emergence of A. artemisiifolia tended to be the lowest in both 5-month and 1-month recipient communities, C. selloana showed the highest seedling 
emergence in 1-month communities (Figure 3.4A,C). This suggests that the communities established for 1 month facilitated $C$. selloana seedling emergence through the creation of better conditions than bare soil, probably by retaining humidity and generating adequate shade conditions (Domenech 2005; Holmgren et al. 1997).

The interaction between time advance and species composition of the recipient community best explained variations in seedling emergence of B. barbinodis (Figure 3.4B). Species composition impacted seedling emergence in 5-month communities, where seedling emergence was lower in polycultures; however, it had no impact in 1-month communities. It seems unlikely that the effect of species composition in 5month polycultures is driven by variations in vegetation cover or soil parameters, which were similar to monocultures at the time of invasive species introduction (Supplementary material, Figure S3.4, Table S3.2). We therefore hypothesize that a higher overlap between resident species foliage occurred in 5month polycultures (likely more productive than monocultures; Figure 3.6), generating variations in the light environment that impacted B. barbinodis germination (Benech-Arnold et al. 2000). Also, we suggest that the absence of impact of species composition in 1-month communities may be due to the similarities in cover, nutrient contents, and biomass production between the different communities at this very early growth stage. These results imply that the species composition contribution to invasion resistance may vary depending on the stage of community growth, and on the invasive species.

\subsection{Time advance interacted with species composition to determine invasive species survival, density had a limited impact}

Invasive species survival was strongly affected by the species composition of the recipient community. Species composition alone determined B. barbinodis survival, but also strongly influenced, in interaction with other community characteristics, A. artemisiifolia and C. selloana survival. An identical response pattern was observed for the three invasive species: 3-sp and 9-sp communities reduced the invasives' survival to the same extent: the survival rate was lower than in monocultures, where it remained comparable to bare soil (Figure 3.5). This pattern appeared strongly correlated to total aboveground biomass production of the recipient communities: biomass production was 3 to 4 times lower in monocultures than in polycultures. Another factor, however, is that 3-sp and 9-sp communities were dominated by two different species (T. repens and L. corniculatus respectively; Figure 3.6). Therefore, we found that the total biomass produced explained the enhanced invasion resistance in polycultures rather than the number of species (i.e. high species richness is often associated with increased resistance to invasion at small scales; (Byun et al. 2013; Dukes 2002; Fargione \& Tilman 2005; Kennedy et al. 2002; Levine \& D’Antonio 1999), or the identity of the dominant species.

The prevalent role of biomass was also highlighted by A. artemisiifolia and $C$. selloana survival patterns. A. artemisiifolia and $C$. selloana survival was influenced by the interaction between time advance and species composition (Figure 3.5A,C). In polycultures, survival was lower in 5-month than 1-month communities, supporting the assumption that a greater time advance increases competitive abilities compared to later-arriving invasive species (Wilsey et al. 2015) and enhances invasion resistance (Orloff et al. 2013; von Gillhaussen et al. 2014; Young et al. 2016). However, time advance did not impact as much monocultures' invasion resistance, most likely due to too low biomass production (Figure 3.6). These results suggest that it is not the time advance per se, but rather the amount of biomass produced (and thus the amount of limiting resource preempted) that determines the size of the competitive advantage given to the previously-established species, and in this case, invasion resistance. Overall, these findings (i.e. biomass prevailing over species composition or time advance) are consistent with previous 
studies showing that stand biomass is a major determinant of invasibility (Lulow 2006; Mason et al. 2017; Rinella et al. 2007).

In most cases, density did not impact early establishment success of the invasive species (Figures 3.4, 3.5). Density only appeared to strongly impact A. artemisiifolia survival in 1-month communities, where higher density tended to decrease the survival rate in polycultures (Figure 3.5A). The higher number of individuals may have led, in very early stages of community growth, to greater resource preemption, thereby hindering A. artemisiifolia survival. The absence of impact from density (1) in 5-month communities may have been caused by biomass stabilization over time (Figure 3.6; von Gillhaussen et al. 2014), and (2) in 1-month monocultures may be due to insufficient aboveground biomass production (Figure 3.6). It is possible that biomass stabilized over time, with both LowD and HighD communities reaching the biomass threshold value (i.e. the carrying capacity) of the habitat. In this case, a further increase in biomass can only be achieved if mortality causes reductions in density and frees up space for survivors (i.e. self-thinning; Crawley 2007; Stoll et al. 2002). Since only one invasive species was impacted by community density, our results provide little support for the hypothesis that increasing density lowers early establishment success of invasive species at the early stage of community growth. However, this should be tested in field conditions, were carrying capacity may be less restrictive.

It appears from our results that extending the time advance of native species on invasive species seed arrival can reinforce priority effects, therefore reducing invasion success on soil cleared of vegetation. How much of an advantage this time advance represents will, however, depend on biomass production. The positive effect could be maximized by clearing soil of invasive species propagules and vegetative parts before rapidly sowing native plant communities, and by carefully controlling invaders during the first few weeks. Eliminating rhizomes fragments may be particularly critical since rhizome emergence is less sensitive to the presence of neighbors than seedling emergence (Kettenring et al. 2015), and rhizomes are likely to have greater overall establishment success than seeds because they are better provisioned (Silvertown 2008; Winkler \& Fischer 2002).

The benefits from giving a time advance to certain species can remain visible for years (Young et al. 2016), so this strategy may also pay off in the long term. In our short-term experiment, the contribution of only a few species to invasion resistance in polycultures implies that establishing a few productive species may be an efficient strategy to repel invasive species colonization at the early stages of community growth. On the other hand, long-term studies suggest that implementing diverse communities may ensure ecosystems against declines in productivity (Lawton \& Brown 1994; Yachi \& Loreau 1999) and reduce biomass and resource-use fluctuations over time (Cottingham et al. 2001; Hooper et al. 2005), potentially leading to greater resistance in the long term (Dunstan \& Johnson 2007). Further research will be needed to determine whether combinations of different seeding strategies (i.e. early sowing of a few productive species, followed by late sowing of species mixtures) can help to reinforce invasion resistance in both short and longer terms.

\section{Acknowledgements}

We are grateful to Corentin Rollet, Lauren Redmond, Samuel Hilaire, Loïc Willm and numerous other colleagues for lab and field assistance. We thank Emilie Luna-Laurent for providing meteorological data. We also acknowledge Anne Scher and Alexandre Valt for inspiring discussions and Marjorie Sweetko for reviewing the English of the paper. No conflicts of interest have been declared. 


\section{References}

Abbott, L.B. and Roundy, B.A. (2003) Available water influences field germination and recruitment of seeded grasses. Journal of Range Management, 56, 56-64. http://doi.org/10.2458/azu_jrm_v56i1_abbott Afnor (1994) Recueil de Normes Françaises (French). Qualité des Sols. Afnor, Paris La Défense, France. Albrecht, M.A. and McCarthy, B.C. (2009) Seedling establishment shapes the distribution of shade- adapted forest herbs across a topographical moisture gradient. Journal of Ecology, 97, 1037-1049. http://doi.org/10.1111/j.1365-2745.2009.01527.x

Allred, K.W. (1981) Cousins to the south: amphitropical disjunctions in southwestern grasses. Desert Plants, 3, 98-106.

Arienzo, M., Adamo, P. and Cozzolino, V. (2004) The potential of Lolium perenne for revegetation of contaminated soil from a metallurgical site. Science of the Total Environment, 319, 13-25. http://doi.org/10.1016/S0048-9697(03)00435-2

Auriault, R. (1975) Bothriochloa imperatoides (Hackel) Herter adventice dans l'Hérault (French). Le Monde des Plantes, 383, 2-3.

Bacchetta, G., Dettori, C.A., Mascia, F., Meloni, F. and Podda, L. (2010) Assessing the potential invasiveness of Cortaderia selloana in Sardinian wetlands through seed germination study. Plant Biosystems, 144, 518-527. http://doi.org/10.1080/11263500903403465

Bae, J., Nurse, R.E., Simard, M.J. and Page, E.R. (2017) Managing glyphosate-resistant common ragweed (Ambrosia artemisiifolia): effect of glyphosate-phenoxy tank mixes on growth, fecundity, and seed viability. Weed Science, 65, 31-40. http://doi.org/10.1614/WS-D-16-00094.1

Bassett, I.J. and Crompton, C.W. (1975) The biology of Canadian weeds. 11. Ambrosia artemisiifolia L. and A. psilostachya DC. Canadian Journal of Plant Science, 55, 463-476. http://doi.org/10.4141/cjps75072

Batlla, D., Kruk, B.C. and Benech- Arnold, R.L. (2000) Very early detection of canopy presence by seeds through perception of subtle modifications in red: far red signals. Functional Ecology, 14, 195-202. http://doi.org/10.1046/j.1365-2435.2000.00418.x

Bazzaz, F.A. (1970) Secondary dormancy in the seeds of the common ragweed Ambrosia artemisiifolia. Bulletin of the Torrey Botanical Club, 97, 302-305. http://doi.org/10.2307/2483650

Benech-Arnold, R.L., Sánchez, R.A., Forcella, F., Kruk, B.C. and Ghersa, C.M. (2000) Environmental control of dormancy in weed seed soil banks. Field Crops Research, 67, 105-122. http://doi.org/10.1016/S0378-4290(00)00087-3

Bossard, C.C., Randall, J.M. and Hoshovsky, M.C. (Eds) (2000) Invasive plants of California's wildlands. Berkeley, CA, USA: University of California Press.

Burton, C.M., Burton, P.J., Hebda, R. and Turner, N.J. (2006) Determining the optimal sowing density for a mixture of native plants used to revegetate degraded ecosystems. Restoration Ecology 14, 379-390. http://doi.org/10.1111/j.1526-100X.2006.00146.x 
Byun, C., Blois, S. and Brisson, J. (2013) Plant functional group identity and diversity determine biotic resistance to invasion by an exotic grass. Journal of Ecology, 101, 128-139. http://doi/org/10.1111/13652745.12016

Byun, C. and Lee, E.J. (2017) Ecological application of biotic resistance to control the invasion of an invasive plant, Ageratina altissima. Ecology and Evolution, 7, 2181-2192. http://doi.org/10.1002/ece3.2799

Carter, D.L. and Blair J.M. (2012) High richness and dense seeding enhance grassland restoration establishment but have little effect on drought response. Ecological Applications, 22, 1308-1319. http://doi.org/10.1890/11-1970.1

Choquet, R., Rouan, L. and Pradel, R. (2009) Program E-Surge: A Software Application for Fitting Multievent Models. In: Thomson, D.L., Cooch, E.G. and Conroy, M.J. (Eds) Modeling Demographic Processes In Marked Populations, Environmental and Ecological Statistics, Vol. 3. Boston, MA, USA: Springer, pp. 845-865.

Cooch, E.G. and White, G. (2019) Chapter 5 - Goodness of fit testing. In: Program MARK - A gentle introduction. Available at http://www.phidot.org/software/mark/docs/book/pdf/chap5.pdf [Accessed 12 June 2019]

Corbin, J.D. and D'Antonio, C.M. (2012) Gone but not forgotten? Invasive plants' legacies on community and ecosystem properties. Invasive Plant Science and Management, 5, 117-124. http://doi.org/10.1614/IPSM-D-11-00005.1

Costas-Lippmann, M. (1979) Embryogeny of Cortaderia selloana and C. jubata (Gramineae). Botanical Gazette, 140, 393-397. http://doi.org/10.1086/337103

Cottingham, K.L., Brown, B.L. and Lennon, J.T. (2001) Biodiversity may regulate the temporal variability of ecological systems. Ecology Letters, 4, 72-85. http://doi.org/10.1046/j.14610248.2001.00189.x

Craine, J.M. and Dybzinski, R. (2013) Mechanisms of plant competition for nutrients, water and light. Functional Ecology, 27, 833-840. http://doi.org/ 10.1111/1365-2435.12081

Crawley, M.J. (2007) Plant population dynamics. In: May, R.M. and McLean, A. (Eds) Theoretical ecology: Principles and applications. Oxford, UK: Oxford University Press, pp. 62-83.

Crawley, M.J., Brown, S.L., Heard, M.S. and Edwards, G.R. (1999) Invasion resistance in experimental grassland communities: species richness or species identity?. Ecology Letters, 2, 140-148. http://doi.org/10.1046/j.1461-0248.1999.00056.x

Davis, M.A., Grime, J.P. and Thompson, K. (2000) Fluctuating resources in plant communities: a general theory of invasibility. Journal of Ecology, 88, 528-534. http://doi.org/10.1046/j.1365-2745.2000.00473.x

Delory, B.M., Weidlich, E.W., Kunz, M., Neitzel, J. and Temperton, V.M. (2019) The exotic species Senecio inaequidens pays the price for arriving late in temperate European grassland communities. Oecologia, 191, 657-671. http://doi.org/10.1007/s00442-019-04521-x

Dinno, A. (2015) Nonparametric pairwise multiple comparisons in independent groups using Dunn's test. The Stata Journal, 15, 292-300. http://doi.org/10.1177/1536867X1501500117 
Domenech, R. (2005). Cortaderia selloana invasion in the Mediterranean region: Invasiveness and ecosystem invasibility. PhD dissertation, Universitat Autònoma de Barcelona, Bellaterra, Barcelona, Spain.

Domenech, R. and Vila, M. (2007) Cortaderia selloana invasion across a Mediterranean coastal strip. Acta Oecologica, 32, 255-261. http://doi.org/10.1016/j.actao.2007.05.006

Domenech, R. and Vila, M. (2008) Response of the invader Cortaderia selloana and two coexisting natives to competition and water stress. Biological Invasions, 10, 903-912. http://doi.org/10.1007/s10530008-9243-0

Dukes, J.S. (2002) Species composition and diversity affect grassland susceptibility and response to invasion. Ecological Applications, 12, 602-617. http:// 10.1890/10510761(2002)012[0602:SCADAG]2.0.CO;2

Dunstan, P.K. and Johnson, C.R. (2007) Mechanisms of invasions: can the recipient community influence invasion rates?. Botanica Marina, 50, 361-372. http:// 10.1515/BOT.2007.041

Ejrnæs, R., Bruun, H.H. and Graae, B.J. (2006) Community assembly in experimental grasslands: Suitable environment or timely arrival?. Ecology, 87, 1225-1233. http://doi.org/ 10.1890/00129658(2006)87[1225:CAIEGS]2.0.CO;2

Emery, S.M. (2007) Limiting similarity between invaders and dominant species in herbaceous plant communities?. Journal of Ecology, 95, 1027-1035.

Facon, B., Genton, B.J., Shykoff, J., Jarne, P., Estoup, A. and David, P. (2006) A general ecoevolutionary framework for understanding bioinvasions. Trends in Ecology and Evolution, 21, 130-135. http://doi.org/10.1016/j.tree.2005.10.012

Fargione, J.E. and Tilman, D. (2005) Diversity decreases invasion via both sampling and complementarity effects. Ecology Letters, 8, 604-611. http://doi.org/10.1111/j.1461-0248.2005.00753.x

Firn, J., MacDougall, A.S., Schmidt, S. and Buckley, Y.M. (2010) Early emergence and resource availability can competitively favour natives over a functionally similar invader. Oecologia, 163, 775784. http://doi.org/10.1007/s00442-010-1583-7

Fried, G. (2010). Prioritization of potential invasive alien plants in France. In: Brunel, S., Uludag, A., Fernandez-Galiano, E. and Brundu, G. (Eds) 2nd International Workshop Invasive Plants in the Mediterranean Type Regions of the World. Trabzon, Turkey, pp. 120-138.

Fried, G. (Eds) (2014) Guide des plantes invasives (French). Paris, France: Belin.

Fukami, T. (2015) Historical contingency in community assembly: integrating niches, species pools, and priority effects. Annual Review of Ecology, Evolution and Systematics, 46, 1-23. http://doi.org/10.1146/annurev-ecolsys-110411-160340

Fumanal, B. (2007) Caractérisation des traits biologiques et des processus évolutifs d'une espèce envahissante en France: Ambrosia artemisiifolia L. (French). PhD disseration, Bourgogne University, Dijon, France.

Gargominy, O., Tercerie, S., Régnier, C., Ramage, T., Dupont, P., Daszkiewicz, P. et al. (2019) TAXREF v13, référentiel taxonomique pour la France : méthodologie, mise en œuvre et diffusion (French). Paris, France : Muséum national d'Histoire naturelle. 
Gerhardt, F. and Collinge, S.K. (2007) Abiotic constraints eclipse biotic resistance in determining invasibility along experimental vernal pool gradients. Ecological Applications, 17, 922-933. http://doi.org/10.1890/05-1146

von Gillhaussen, P., Rascher, U., Jablonowski, N.D., Plückers, C., Beierkuhnlein, C. and Temperton V.M. (2014) Priority effects of time of arrival of plant functional groups override sowing interval or density effects: a grassland experiment. PloS One, 9, e86906. http://doi.org/10.1371/journal.pone.0086906

Goldberg, D.E., Turkington, R., Olsvig-Whittaker, L. and Dyer, A.R. (2001) Density dependence in an annual plant community: variation among life history stages. Ecological Monographs, 71, 423-446. http://doi.org/10.1890/0012-9615(2001)071[0423:DDIAAP]2.0.CO;2

Goldstein, L.J. and Suding, K.N. (2014) Applying competition theory to invasion: resource impacts indicate invasion mechanisms in California shrublands. Biological Invasions, 16, 191-203. http://doi.org/10.1007/s10530-013-0513-0

Grman, E. and Suding, K.N. (2010) Within-year soil legacies contribute to strong priority effects of exotics on native California grassland communities. Restoration Ecology, 18, 664-670. http:// 10.1111/j.1526-100X.2008.00497.x

Harper, J.L. (1961) Approaches to the study of plant competition. Society for Experimental Biology Symposia, 15, 1-39.

Heckel, M.E. (1906) Sur l'Ambrosia artemisiaefolia L. et sa naturalisation en France (French). Bulletin de la Société Botanique de France, 53, 600-620. http://doi.org/ 10.1080/00378941.1906.10831212

Helsen, K., Hermy, M. and Honnay, O. (2016) A test of priority effect persistence in semi-natural grasslands through the removal of plant functional groups during community assembly. BMC Ecology, 16, 22. http://doi.org/10.1186/s12898-016-0077-9

Hess, M.C.M., Mesléard, F. and Buisson, E. (2019) Priority effects: Emerging principles for invasive plant species management. Ecological Engineering, 127, 48-57. http://doi.org/10.1016/j.ecoleng.2018.11.011

Hobbs, R.J. and Huenneke, L.F. (1992) Disturbance, diversity, and invasion: implications for conservation. Conservation Biology, 6, 324-337. http://doi.org/10.1046/j.1523-1739.1992.06030324.x

Holmgren, M., Scheffer, M. and Huston, M.A. (1997) The interplay of facilitation and competition in plant communities. Ecology, 78, 1966-1975. http://doi.org/10.1890/00129658(1997)078[1966:TIOFAC]2.0.CO;2

Hooper, D.U., Chapin, F.S., Ewel, J.J., Hector, A., Inchausti, P., Lavorel, S. et al. (2005) Effects of biodiversity on ecosystem functioning: a consensus of current knowledge. Ecological Monographs, 75, 335. http://doi.org/10.1890/04-0922

Kardol, P., Souza, L. and Classen, A.T. (2013) Resource availability mediates the importance of priority effects in plant community assembly and ecosystem function. Oikos, 122, 84-94. http://doi.org/10.1111/j.1600-0706.2012.20546.x

Kennedy, T.A., Naeem, S., Howe, K.M., Knops, J.M., Tilman, D. and Reich, P. (2002) Biodiversity as a barrier to ecological invasion. Nature, 417, 636-638. http://doi.org/10.1038/nature00776 
Kettenring, K. M., Whigham, D. F., Hazelton, E. L., Gallagher, S. K. and Weiner, H. M. (2015) Biotic resistance, disturbance, and mode of colonization impact the invasion of a widespread, introduced wetland grass. Ecological Applications, 25, 466-480. http://doi.org/10.1890/14-0434.1

Kitajima, K. and Fenner, M. (2000) Ecology of seedling regeneration. In: Fenner, M. (Eds) Seeds: the ecology of regeneration in plant communities. Wallingford: CABI Publishing, pp. 331-359.

Koller, D., Kozlowski, T.T. (1972) Environmental control of seed germination. In: Kozlowski T.T. (Ed) Seed biology, Vol. 2. New York, NY, USA: Academic Press, pp. 1-101.

Körner, C., Stöcklin, J., Reuther-Thiébaud, L. and Pelaez- Riedl, S. (2008) Small differences in arrival time influence composition and productivity of plant communities. New Phytologist, 177, 698-705. http://doi.org/10.1111/j.1469-8137.2007.02287.x

Koshi, P.T., Eck, H.V., Stubbendieck, J. and McCully, W.G. (1977) Cane bluestems: Forage yield, forage quality, and water-use efficiency. Journal of Range Management, 30, 190-193. http://doi.org/10.2307/3897465

Lambrinos, J.G. (2002) The variable invasive success of Cortaderia species in a complex landscape. Ecology, 83, 518-529. http://doi.org/10.1890/0012-9658(2002)083[0518:TVISOC]2.0.CO;2

Larson, D.L., Bright, J.B., Drobney, P., Larson, J.L., Palaia, N., Rabie, P.A. et al. (2013) Using prairie restoration to curtail invasion of Canada thistle: the importance of limiting similarity and seed mix richness. Biological Invasions, 15, 2049-2063. http://doi.org/10.1007/s10530-013-0432-0

Lavoie, C., Jodoin, Y. and De Merlis, A.G. (2007) How did common ragweed (Ambrosia artemisiifolia L.) spread in Quebec? A historical analysis using herbarium records. Journal of Biogeography, 34, 1751 1761. http://doi.org/10.1111/j.1365-2699.2007.01730.x

Lawton, J.H. and Brown, V.K. (1993) Redundancy in Ecosystems. In: Schulze, E.D. and Mooney, H. (Eds) Biodiversity and Ecosystem function. Berlin, Germany: Springer, pp. 255-270.

Lebreton, J.D. and Pradel, R. (2002) Multistate recapture models: Modelling incomplete individual histories. Journal of Applied Statistics, 29, 353-369. http://doi.org/ 10.1080/02664760120108638

Lebreton, J.D., Nichols, J.D., Barker, R.J., Pradel, R. and Spendelow, J.A. (2009) Chapter 3 Modeling Individual Animal Histories with Multistate Capture-Recapture Models. Advances in Ecological Research, 41, 87-173. http://doi.org/10.1016/S0065-2504(09)00403-6

Leskovšek, R., Datta, A., Simoncic, A. and Knezevic, S.Z. (2012) Influence of nitrogen and plant density on the growth and seed production of common ragweed (Ambrosia artemisiifolia L.). Journal of Pest Science, 85, 527-539. http://doi.org/10.1007/s10340-012-0433-2

Levine, J.M., Adler, P.B. and Yelenik, S.G. (2004) A meta- analysis of biotic resistance to exotic plant invasions. Ecology Letters, 7, 975-989. http://doi.org/10.1111/j.1461-0248.2004.00657.x

Levine, J.M. and D'Antonio, C.M. (1999) Elton revisited: a review of evidence linking diversity and invasibility. Oikos, 1, 15-26. http://doi.org/10.2307/3546992

Lionello, P., Malanotte-Rizzoli, P., Boscolo, R., Alpert, P., Artale, V., Li, L. et al. (2006) The Mediterranean climate: an overview of the main characteristics and issues. In: Lionello, P., MalanotteRizzoli, P. and Boscolo, R. (Eds) Developments in earth and environmental sciences Vol. 4. Amsterdam, Netherlands: Elsevier, pp. 1-26. 
Lulow, M.E. (2006) Invasion by non- native annual grasses: the importance of species biomass, composition, and time among California native grasses of the Central Valley. Restoration Ecology, 14, 616-626. http://doi.org/10.1111/j.1526-100X.2006.00173.x

Mangla, S. and Callaway, R.M. (2008) Exotic invasive plant accumulates native soil pathogens which inhibit native plants. Journal of Ecology, 96, 58-67. http://doi.org/ 10.1111/j.1365-2745.2007.01312.x

Mason, T.J., French, K. and Jolley, D.F. (2017) Functional richness and identity do not strongly affect invasibility of constructed dune communities. PloS One, 12:e0169243. http://doi.org/10.1371/journal.pone.0169243

Middleton, E.L., Bever, J.D. and Schultz, P.A. (2010) The effect of restoration methods on the quality of the restoration and resistance to invasion by exotics. Restoration Ecology, 18, 181-187. http://doi.org/10.1111/j.1526-100X.2008.00501.x

Mollot, G., Pantel, J.H. and Romanuk, T.N. (2017) The effects of invasive species on the decline in species richness: a global meta-analysis. Advances in Ecological Research, 56, 61-83. http://doi.org/10.1016/bs.aecr.2016.10.002

Nemec, K.T., Allen, C.R., Helzer, C.J. and Wedin, D.A. (2013) Influence of richness and seeding density on invasion resistance in experimental tallgrass prairie restorations. Ecological Restoration, 31, 168-185. http://doi.org/10.3368/er.31.2.168

NF ISO 112361, 1995. Soil Quality - Determination of total nitrogen - modified Kjeldahl method. International Organization for Standardization, Geneve, Switzerland.

NF ISO 14235, 1998. Soil Quality - Determination of organic carbon by sulfochromic oxidation. International Organization for Standardization, Geneve, Switzerland

NF ISO 14259-2, 2007. Soil Quality - Determination of nitrate, nitrite and ammonium content in crude soils by extraction with potassium and chloride solution - Part 2: automated method with segmented flow analysis. International Organization for Standardization, Geneve, Switzerland

NF X31-160, 1999. Soil Quality - Determination of soluble phosphorus in a 20g/l solution of citric acid monohydrate - Dyer Method. Association Française de Normalisation, Paris, France

Onen, H., Farooq, S., Gunal, H., Ozaslan, C. and Erdem, H. (2017) Higher Tolerance to Abiotic Stresses and Soil Types May Accelerate Common Ragweed (Ambrosia artemisiifolia) Invasion. Weed Science, 65, 115-127. http://doi.org/10.1614/WS-D-16-00011.1

Orloff, L.N., Mangold, J.M. and Menalled, F.D. (2013) Role of size and nitrogen in competition between annual and perennial grasses. Invasive Plant Science and Management, 6, 87-98. http://10.1614/IPSM-D$12-00035.1$

Ozaslan, C., Onen, H., Farooq, S., Gunal, H. and Akyol, N. (2016) Common ragweed: an emerging threat for sunflower production and human health in Turkey. Weed Biology and Management, 16, 42-55. http://doi.org/10.1111/wbm.12093

Pons, T.L. (1989) Breaking of seed dormancy by nitrate as a gap detection mechanism. Annals of Botany, 63, 139-143. http://doi.org/10.1093/oxfordjournals.aob.a087716

Rinella, M.J., Pokorny, M.L. and Rekaya, R. (2007) Grassland invader responses to realistic changes in native species richness. Ecological Applications, 17, 1824-1831. http://doi.org/10.1890/06-1881.1 
Ross, M.A. and Harper, J.L. (1972) Occupation of biological space during seedling establishment. Journal of Ecology, 60, 77-88. http://doi.org/ 10.2307/2258041

Sagar, G.R and Harper, J.L. (1960) Factors affecting the germination and early establishment of plantains (Plantago lanceolata, P. media and P. major). In: Harper, J.L. (Ed) The biology of weeds. Oxford, England: Blackwell, pp. 236-244.

Seebens, H., Blackburn, T.M., Dyer, E.E., Genovesi, P., Hulme, P.E., Jeschke, J.M et al. (2017) No saturation in the accumulation of alien species worldwide. Nature Communications, 8, 1-9. http://doi.org/10.1038/ncomms14435

Silvertown, J. (2008) The evolutionary maintenance of sexual reproduction: evidence from the ecological distribution of asexual reproduction in clonal plants. International Journal of Plant Sciences, 169, 157168. http://doi.org/ 10.1086/523357

Simard, M.J. and Benoit, D.L. (2010) Distribution and abundance of an allergenic weed, common ragweed (Ambrosia artemisiifolia L.), in rural settings of southern Quebec, Canada. Canadian Journal of Plant Science, 90, 549-557. http://doi.org/10.4141/CJPS09174

Stewart, A.M., Edmisten, K.L., Wells, R. and Collins, G.D. (2007) Measuring canopy coverage with digital imaging. Communications in Soil Science Plant Analysis, 38, 895-902. http://doi.org/10.1080/00103620701277718

Stoll, P., Weiner, J., Muller-Landau, H., Müller, E. and Hara, T. (2002) Size symmetry of competition alters biomass-density relationships. Proceedings of the Royal Society B in Biological Sciences, 269, 2191-2195. http://doi.org/10.1098/rspb.2002.2137

Vaughn, K.J. and Young, T.P. (2015) Short-term priority over exotic annuals increases the initial density and longer-term cover of native perennial grasses. Ecological Applications, 25, 791-799. http://doi.org/ 10.1890/14-0922.1

Vega, A.S. (2000) Revisión taxonómica de las especies americanas del género Bothriochloa (Poaceae: Panicoideae: Andropogoneae) (Spanish). Darwiniana, 38, 127-186.

Verloove, F. and Sánchez Gullón, E. (2012) New records of interesting vascular plants (mainly xenophytes) in the Iberian Peninsula II. Flora Mediterranea, 22:5-24. http://doi.org/10.7320/FlMedit22.005

de Wet, J.M.J. (1968) Biosystematics of the Bothriochloa barbinodis complex (Gramineae). American Journal of Botany, 55, 1246-1250. http://doi.org/10.1002/j.1537-2197.1968.tb07492.x

Wilsey, B.J., Barber, K. and Martin, L.M. (2015) Exotic grassland species have stronger priority effects than natives regardless of whether they are cultivated or wild genotypes. New Phytologist, 205, 928-937. http://doi.org/10.1111/nph.13028

Winkler, E. and Fischer, M. (2001) The role of vegetative spread and seed dispersal for optimal life histories of clonal plants: a simulation study. Evolutionary Ecology, 15, 281-301. http://doi.org/ 10.1007/978-94-017-1345-0_4

Yannelli, F.A., Hughes, P. and Kollmann, J. (2017) Preventing plant invasions at early stages of revegetation: The role of limiting similarity in seed size and seed density. Ecological Engineering, 100, 286-290. http://doi.org/10.1016/j.ecoleng.2016.12.001 
Yannelli, F.A., Karrer, G., Hall, R., Kollmann, J. and Heger, T. (2018) Seed density is more effective than multi- trait limiting similarity in controlling grassland resistance against plant invasions in mesocosms. Applied Vegetation Science, 21, 411-418. http://doi.org/10.1111/avsc.12373

Yachi, S. and Loreau, M. (1999) Biodiversity and ecosystem productivity in a fluctuating environment: the insurance hypothesis. Proceedings of the National Academy of Sciences of the United States of America, 96, 1463-1468. http://doi.org/10.1073/pnas.96.4.1463

Young, T.P., Stuble, K.L., Balachowski, J.A, and Werner, C.M. (2016) Using priority effects to manipulate competitive relationships in restoration. Restoration Ecology, 25, 114-123. http://doi.org/10.1111/rec.12384 


\section{Supplementary material}

Table S3.1 Results of preliminary invasive species germination tests realized before the experiment and used to define the number of introduced seeds for the three harvested populations (GPS coordinates indicated) of each of the three tested invasive species. Based on the results of preliminary germination rates ('Germination rate'), we determined the theoretical number of seeds required to achieve one emerged individual ('Theoretical No. of seeds'). The final number of seeds introduced ('Applied No. of seeds') was then calculated by rounding the theoretical number of introduced seeds up to the next whole number (i.e. in order to theoretically achieve at least one emerged individual). This adjustment aimed at reducing the bias linked with the intrinsic germination capacity of the harvested invasive species seeds in the experiment.

\begin{tabular}{llccc}
\hline \multicolumn{1}{c}{ Species } & \multicolumn{1}{c}{$\begin{array}{c}\text { Population location } \\
\text { (GPS coordinates) }\end{array}$} & $\begin{array}{c}\text { Germination } \\
\text { rate (\%) }\end{array}$ & $\begin{array}{c}\text { Theoretical } \\
\text { No. of seeds }\end{array}$ & $\begin{array}{c}\text { Applied No. } \\
\text { of seeds }\end{array}$ \\
\hline \multirow{4}{*}{ A. artemisiifolia } & Pop. $1: 44^{\circ} 0^{\prime} 443^{\prime \prime} \mathrm{N}, 4^{\circ} 52^{\prime} 13.8^{\prime \prime} \mathrm{E}$ & 67.5 & 1.48 & 2 \\
& Pop. $2: 43^{\circ} 54^{\prime} 27.2^{\prime \prime} \mathrm{N}, 4^{\circ} 52^{\prime} 13.8^{\prime \prime} \mathrm{E}$ & 23.9 & 4.18 & 5 \\
& Pop. $3: 43^{\circ} 51^{\prime} 57.1^{\prime \prime} \mathrm{N}, 4^{\circ} 35^{\prime} 46.8^{\prime \prime} \mathrm{E}$ & 67.5 & 1.48 & 2 \\
\hline \multirow{3}{*}{ B. barbinodis } & Pop. $1: 43^{\circ} 33^{\prime} 23.1^{\prime \prime} \mathrm{N}, 4^{\circ} 19^{\prime} 16.1^{\prime \prime} \mathrm{E}$ & 89.7 & 1.11 & 2 \\
& Pop. $2: 43^{\circ} 40^{\prime} 7.9^{\prime \prime} \mathrm{N}, 3^{\circ} 58^{\prime} 31.9^{\prime \prime} \mathrm{E}$ & 25.8 & 3.88 & 4 \\
& Pop. $3: 43^{\circ} 39^{\prime} 39.9^{\prime \prime} \mathrm{N}, 4^{\circ} 38^{\prime} 28.6^{\prime \prime} \mathrm{E}$ & 69.4 & 1.44 & 2 \\
\hline \multirow{3}{*}{ C. selloana } & Pop. $1: 43^{\circ} 41^{\prime} 47.1^{\prime \prime} \mathrm{N}, 4^{\circ} 38^{\prime} 41.1^{\prime \prime} \mathrm{E}$ & 38.6 & 2.59 & 3 \\
& Pop. $2: 43^{\circ} 23^{\prime} 22.9^{\prime \prime} \mathrm{N}, 4^{\circ} 34^{\prime} 28.1^{\prime \prime} \mathrm{E}$ & 46.0 & 2.17 & 3 \\
& Pop. $3: 43^{\circ} 23^{\prime} 50.3^{\prime \prime} \mathrm{N}, 5^{\circ} 7^{\prime} 54.6^{\prime \prime} \mathrm{E}$ & 64.2 & 1.56 & 2 \\
\hline
\end{tabular}

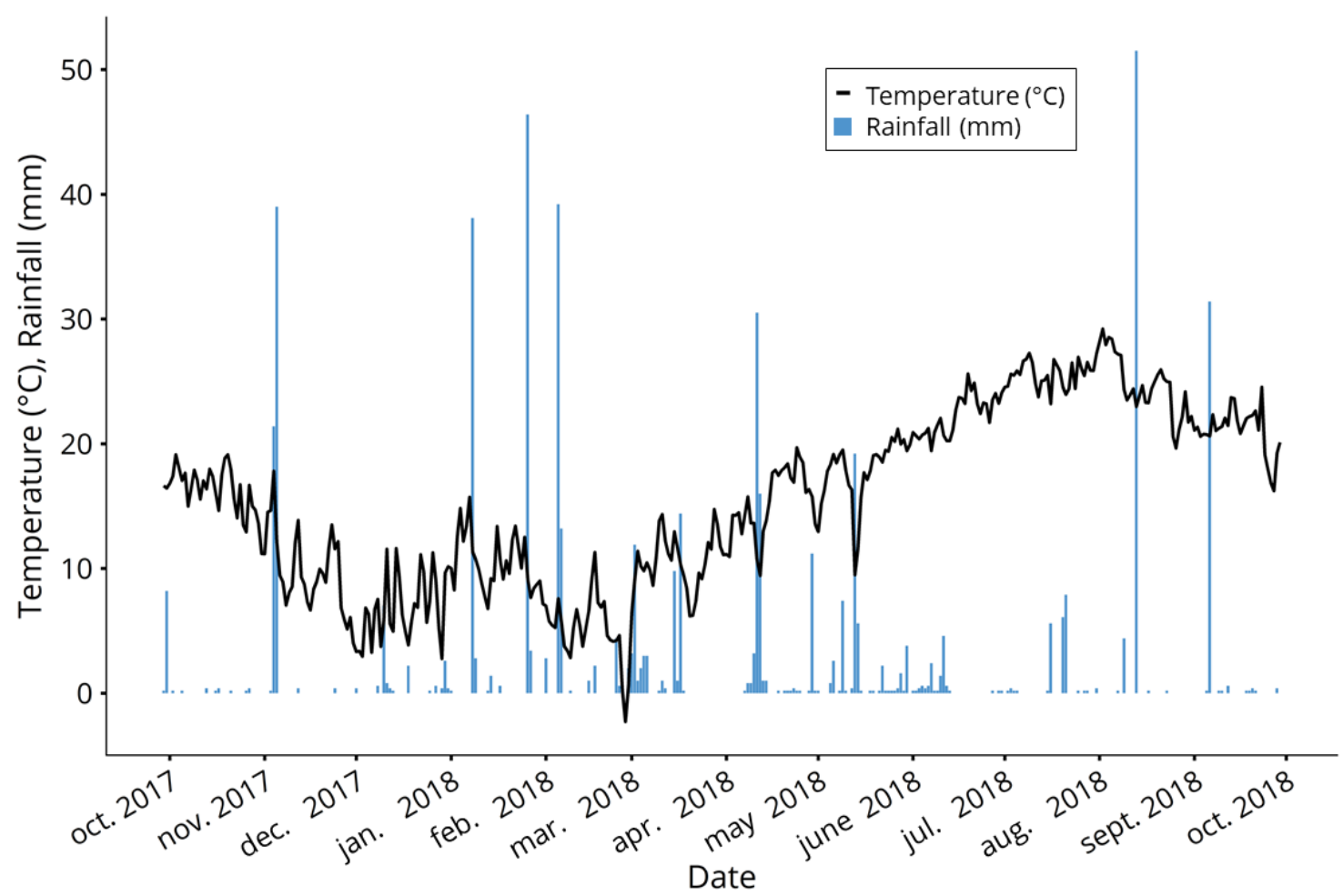

Figure S3.1 Temperature (daily mean in ${ }^{\circ} \mathrm{C}$ ) and rainfall (daily sum in $\mathrm{mm}$ ) recorded during the experiment (Meteo France station number 133004003, Tour du Valat domain, France). 


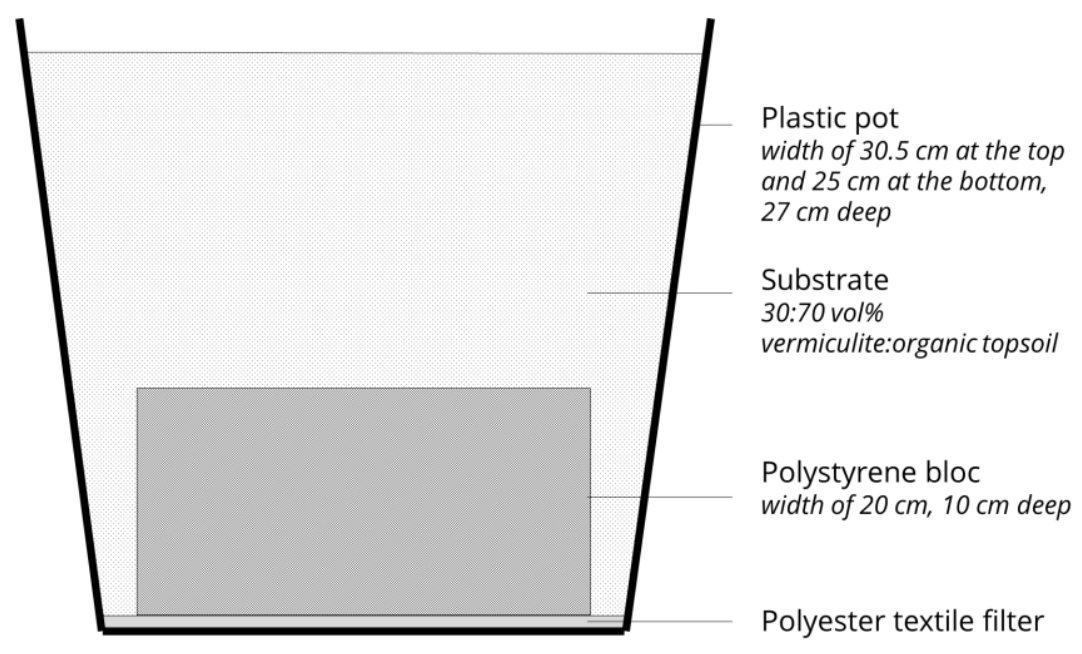

Figure S3.2 Experimental design: pot filling. 
Supplementary material S3.I Description of Capture-Marking-Recapture modeling

\section{Matrices}

The model considered thtrr states, the seed state (S), the plant state (P), and the dead state (D) to estimate two transition probabilities: seedling emergence $(\psi)$ and daily survival $(\varphi)$ :

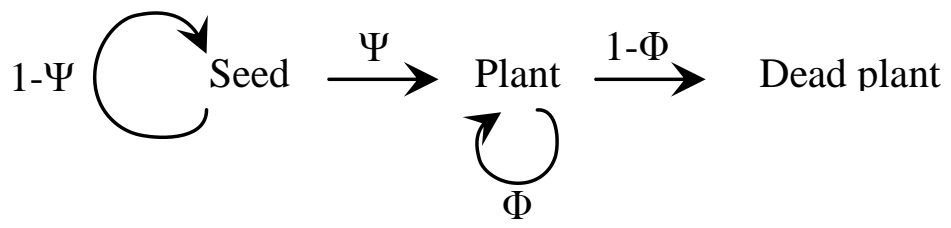

Individual life history in the context of the study protocol

\section{Initi}

al State: At the initial state, all individuals are in the seed state

$$
\begin{aligned}
& S \quad P \\
& \left(\begin{array}{ll}
* & -
\end{array}\right)
\end{aligned}
$$

With '*' indicating the complementarity parameter (only one '*' by row) and ' - ' indicating parameters constrained to zero

Transition 1: Estimation of seedling emergence $(\psi)$

$$
\begin{aligned}
& S \quad P \quad D \\
& \begin{array}{lll}
S \\
P \\
D
\end{array}\left(\begin{array}{lll}
* & \psi & - \\
- & - & -
\end{array}\right)
\end{aligned}
$$

Transition 2: Estimation of daily survival $(\varphi)$

$$
\begin{aligned}
& \begin{array}{lll}
S & P & D
\end{array}
\end{aligned}
$$

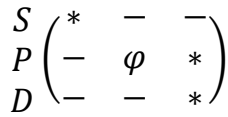

Recapture: Detection probability

Detection probability $(p)$ was equal to 1 so the non-observed rate $(N O)$ was equal to 0 .

$$
\begin{aligned}
& \text { NO S P } \\
& \begin{array}{l}
S \\
P(* \\
D
\end{array}\left(\begin{array}{lll}
* & p & - \\
* & - & -
\end{array}\right)
\end{aligned}
$$


Supplementary material S3.II Model selection for invasive species seedling emergence and survival

\section{Ambrosia artemisiifolia}

Model selection for seedling emergence probabilities with survival probabilities [ $\varphi$ timexcomp $\times$ den] for A. artemisiifolia. Models are ranked by decreasing value of QAICC, with the best model in bold. Number of estimable parameters (NP) and model deviance are also given.

\begin{tabular}{|c|c|c|c|c|}
\hline Model & Seedling emergence & NP & Deviance & QAICc \\
\hline 7 & $\psi$ time & 16 & 2765.85 & 2797.94 \\
\hline 3 & $\psi$ den $\times$ time & 18 & 2764.46 & 2800.58 \\
\hline 4 & $\psi$ comp $\times$ time & 20 & 2761.51 & 2801.66 \\
\hline 1 & $\psi$ den $\times$ comp $\times$ time & 26 & 2751.82 & 2804.06 \\
\hline 5 & $\psi$ den & 16 & 2794.73 & 2826.62 \\
\hline 6 & $\psi$ comp & 19 & 2790.90 & 2829.03 \\
\hline 2 & $\psi$ den $\times$ comp & 20 & 2789.63 & 2829.77 \\
\hline 8 & $\psi$ & 14 & 2807.59 & 2835.66 \\
\hline
\end{tabular}

Model selection for daily plant survival probabilities with best model for emergence probabilities [ $\psi$ time] for $A$. artemisiifolia. Models are ranked by decreasing value of QAICc, with the best model in bold. Number of estimable parameters (NP) and model deviance are also given.

\begin{tabular}{cllll}
\hline Model & \multicolumn{1}{c}{ Survival } & NP & Deviance & QAICc \\
\hline $\mathbf{7}$ & den $\times$ comp $\times$ time & $\mathbf{1 6}$ & $\mathbf{2 7 6 5 . 8 5}$ & $\mathbf{2 7 9 7 . 9 4}$ \\
11 & $\varphi$ comp $\times$ time & 10 & 2781.09 & 2801.12 \\
9 & $\varphi$ den $\times$ comp & 10 & 2802.37 & 2822.41 \\
13 & $\varphi$ comp & 7 & 2812.60 & 2826.62 \\
10 & $\varphi$ den $\times$ comp & 8 & 3018.89 & 3034.91 \\
14 & $\varphi$ time & 6 & 3028.34 & 3040.36 \\
12 & $\varphi$ den & 6 & 3038.61 & 3050.62 \\
15 & $\varphi$. & 4 & 3086.95 & 3094.97 \\
\hline
\end{tabular}




\section{Bothriochloa barbinodis}

Model selection for seedling emergence probabilities with survival probabilities [ $\varphi$ timexcomp $\times$ den] for $B$. barbinodis. Models are ranked by decreasing value of QAICc, with the best model in bold. Number of estimable parameters (NP) and model deviance are also given.

\begin{tabular}{|c|c|c|c|c|}
\hline Model & Seedling emergence & NP & Deviance & QAICc \\
\hline 4 & $\Psi$ comp $\times$ time & 20 & 3052.50 & 3092.64 \\
\hline 1 & $\psi$ den $\times$ comp $\times$ time & 26 & 3043.41 & 3095.64 \\
\hline 7 & $\psi$ time & 16 & 3106.91 & 3138.10 \\
\hline 3 & $\psi$ den $\times$ time & 18 & 3105.29 & 3141.40 \\
\hline 6 & $\psi$ comp & 17 & 3141.23 & 3175.33 \\
\hline 2 & $\psi$ den $\times$ comp & 20 & 3137.28 & 3177.42 \\
\hline 5 & $\psi$ den & 16 & 3166.56 & 3198.65 \\
\hline 8 & $\psi$ & 14 & 3172.94 & 3201.01 \\
\hline
\end{tabular}

Model selection for daily plant survival probabilities with best model for emergence probabilities [ $\psi$ timexcomp] for $B$. barbinodis. Models are ranked by decreasing value of QAICc, with the best model in bold. Number of estimable parameters (NP) and model deviance are also given.

\begin{tabular}{clllc}
\hline Model & \multicolumn{1}{c}{ Survival } & NP & Deviance & QAICc \\
\hline $\mathbf{9}$ & den $\times$ comp & $\mathbf{1 4}$ & $\mathbf{3 0 6 4 . 2 3}$ & $\mathbf{3 0 9 2 . 3 0}$ \\
4 & $\varphi$ den $\times$ comp $\times$ time & 20 & 3052.50 & 3092.64 \\
13 & $\varphi$ comp & 11 & 3070.70 & 3092.75 \\
11 & $\varphi$ comp $\times$ time & 14 & 3065.32 & 3093.39 \\
14 & $\varphi$ time & 10 & 3282.99 & 3303.02 \\
10 & $\varphi$ den $\times$ time & 12 & 3281.66 & 3305.71 \\
12 & $\varphi$ den & 10 & 3287.51 & 3307.54 \\
15 & $\varphi$. & 14 & 3337.65 & 3353.68 \\
\hline
\end{tabular}




\section{Cortaderia selloana}

Model selection for seedling emergence probabilities with survival probabilities [ $\varphi$ timexcomp $\times$ den] for C. selloana. Models are ranked by decreasing value of QAICC, with the best model in bold. Number of estimable parameters (NP) and model deviance are also given.

\begin{tabular}{cllcc}
\hline Model & Seedling emergence & NP & Deviance & QAICc \\
\hline $\mathbf{7}$ & time & $\mathbf{1 6}$ & $\mathbf{3 5 0 4 . 4 6}$ & $\mathbf{3 5 3 6 . 5 6}$ \\
3 & $\psi$ den $\times$ time & 18 & 3503.29 & 3539.42 \\
4 & $\psi$ comp $\times$ time & 20 & 3499.37 & 3539.52 \\
8 & $\psi \cdot$ & 14 & 3516.59 & 3544.67 \\
6 & $\psi$ comp & 17 & 3512.23 & 3546.34 \\
5 & $\psi$ den & 16 & 3514.37 & 3546.47 \\
1 & $\psi$ den $\times$ comp $\times$ time & 26 & 3495.14 & 3547.40 \\
2 & $\psi$ den $\times$ comp & 20 & 3510.29 & 3550.45 \\
\hline
\end{tabular}

Model selection for daily plant survival probabilities with best model for emergence probabilities [ $\psi$ time] for $C$. selloana. Models are ranked by decreasing value of QAICC, with the best model in bold. Number of estimable parameters (NP) and model deviance are also given.

\begin{tabular}{|c|c|c|c|c|}
\hline Model & Survival & NP & Deviance & QAICc \\
\hline 11 & $\varphi \operatorname{comp} \times$ time & 10 & 3510.30 & 3530.34 \\
\hline 7 & $\varphi$ den $\times$ comp $\times$ time & 16 & 3504.46 & 3536.56 \\
\hline 13 & $\varphi$ comp & 7 & 3539.91 & 3553.93 \\
\hline 9 & $\varphi$ den $\times$ comp & 10 & 3534.68 & 3554.72 \\
\hline 14 & $\varphi$ time & 6 & 3652.54 & 3664.55 \\
\hline 10 & $\varphi$ den $\times$ time & 8 & 3650.52 & 3666.55 \\
\hline 12 & $\varphi d e n$ & 6 & 3668.1691 & 3680.19 \\
\hline 15 & $\varphi$. & 4 & 3680.52 & 3688.52 \\
\hline
\end{tabular}




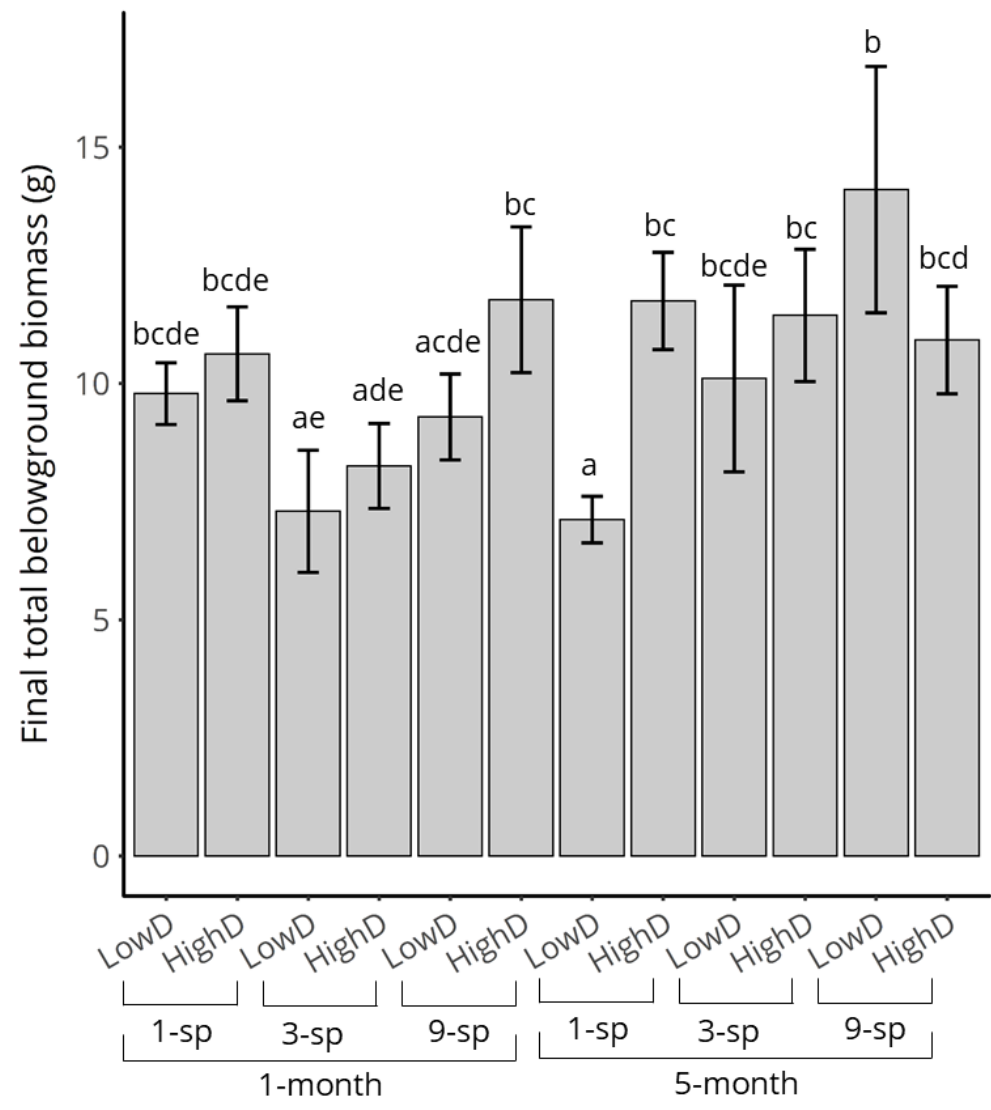

Figure S3.3 Final total belowground biomass (mean $\pm S E, n=6$ ) depending on recipient community type: time advance over invasive species (1- or 5-month), species composition ( $1-\mathrm{sp}=1$ species, 3-sp $=3$ species, $9-\mathrm{sp}=9$ species) and density (LowD = low density or HighD = high density). Community type significantly impacted final total belowground biomass (Kruskal-Wallis $\square^{2}=20.61, d f=11, \quad p=0.038$ ). Increasing density significantly increased belowground biomass only for the 5-month monocultures (post-hoc Dunn's test, $p=0.035)$. Increasing time advance significantly (1) increased belowground biomass for the 3-sp HighD and 9-sp LowD communities (post-hoc Dunn's test, $p=0.031$ and $p=0.042$, respectively) and (2) decreased belowground biomass for the LowD monocultures (post-hoc Dunn's test, $p=0.048$ ). Finally, species composition significantly impacted belowground biomass as following: (1) in LowD 5-month communities, monocultures showed significantly lower belowground biomass than polycultures (post-hoc Dunn's test, $p=0.048$ and $\mathrm{p}=0.001$ for 3-sp and 9-sp, respectively), and (2) in HighD 1-month communities, 3-sp communities showed significantly lower belowground biomass than 9 -sp communities $(p=0.036)$. Letters $(a, b, c, d, e)$ distinguish values that are significantly different according to a post-hoc Dunn's test $(\alpha=0.05)$. 


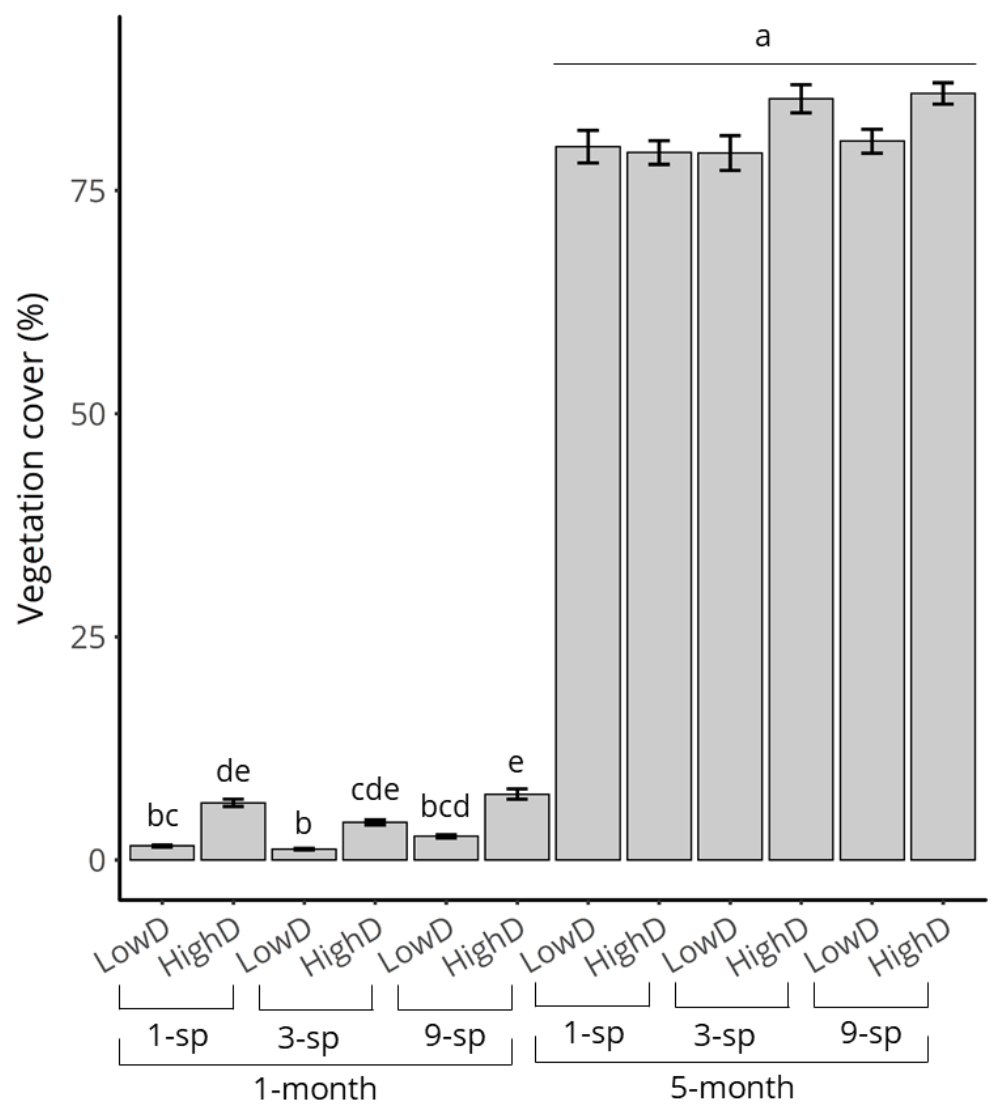

community type: time advance over invasive species (1- or 5-month), species composition (1-sp = 1 species, 3-sp = 3 species, 9-sp = 9 species), and density (LowD = low density or HighD $=$ high density). Letters $(a, b, c, d, e)$ distinguish vegetation cover percentage means that are significantly different according to a post-hoc Dunn's test $(\alpha=0.05)$. 
Table S3.2 Results of soil analyses. Soil parameters depending on community type: time advance over invasive species (1- or 5-month), species composition (1-sp = 1 species, 3-sp = 3 species, 9-sp = 9 species) and density (LowD = low density or HighD = high density). Here, time advance corresponds to the age of the recipient community at the time of soil analyses.

\begin{tabular}{|c|c|c|c|c|c|c|c|c|}
\hline & & & $\begin{array}{c}\text { Total organic } \\
\text { matter }(\%)\end{array}$ & $\mathrm{C}(\mathrm{g} / \mathrm{kg})$ & $\mathrm{N}(\mathrm{g} / \mathrm{kg})$ & $\begin{array}{l}\mathrm{NO}_{3}^{-} \\
(\mathrm{g} / \mathrm{kg})\end{array}$ & $\begin{array}{l}\mathrm{NH}_{4}^{+} \\
(\mathrm{g} / \mathrm{kg})\end{array}$ & $\begin{array}{l}\mathrm{P}_{2} \mathrm{O}_{5} \\
(\mathrm{~g} / \mathrm{kg})\end{array}$ \\
\hline \multicolumn{3}{|c|}{ Control (bare soil) } & 5.1 & 29.5 & 3.54 & 0.092 & 0.0446 & 0.273 \\
\hline \multirow{6}{*}{ 1-month } & \multirow{2}{*}{$1-\mathrm{sp}$} & LowD & 5.1 & 29.6 & 2.39 & 0.042 & 0.0044 & 0.209 \\
\hline & & HighD & 5.0 & 29.1 & 2.72 & 0.032 & 0.0037 & 0.219 \\
\hline & \multirow{2}{*}{$3-\mathrm{sp}$} & LowD & 5.1 & 29.5 & 2.54 & 0.031 & 0.0042 & 0.211 \\
\hline & & HighD & 5.1 & 29.6 & 2.56 & 0.048 & 0.0049 & 0.222 \\
\hline & \multirow{2}{*}{ 9-sp } & LowD & 5.0 & 28.9 & 2.39 & 0.028 & 0.0036 & 0.207 \\
\hline & & HighD & 5.0 & 28.7 & 2.33 & 0.063 & 0.0039 & 0.214 \\
\hline \multirow{6}{*}{ 5-month } & \multirow{2}{*}{$1-\mathrm{sp}$} & LowD & 5.0 & 29.0 & 2.64 & 0.010 & 0.0013 & 0.141 \\
\hline & & HighD & 5.2 & 29.9 & 2.49 & 0.005 & 0.0007 & 0.165 \\
\hline & \multirow{2}{*}{$3-s p$} & LowD & 5.2 & 29.6 & 2.35 & 0.008 & 0.0011 & 0.176 \\
\hline & & HighD & 5.2 & 30.0 & 2.41 & 0.014 & 0.0013 & 0.161 \\
\hline & \multirow{2}{*}{ 9-sp } & LowD & 5.2 & 30.0 & 2.47 & 0.010 & 0.0014 & 0.159 \\
\hline & & HighD & 5.1 & 29.6 & 2.56 & 0.010 & 0.0012 & 0.150 \\
\hline
\end{tabular}



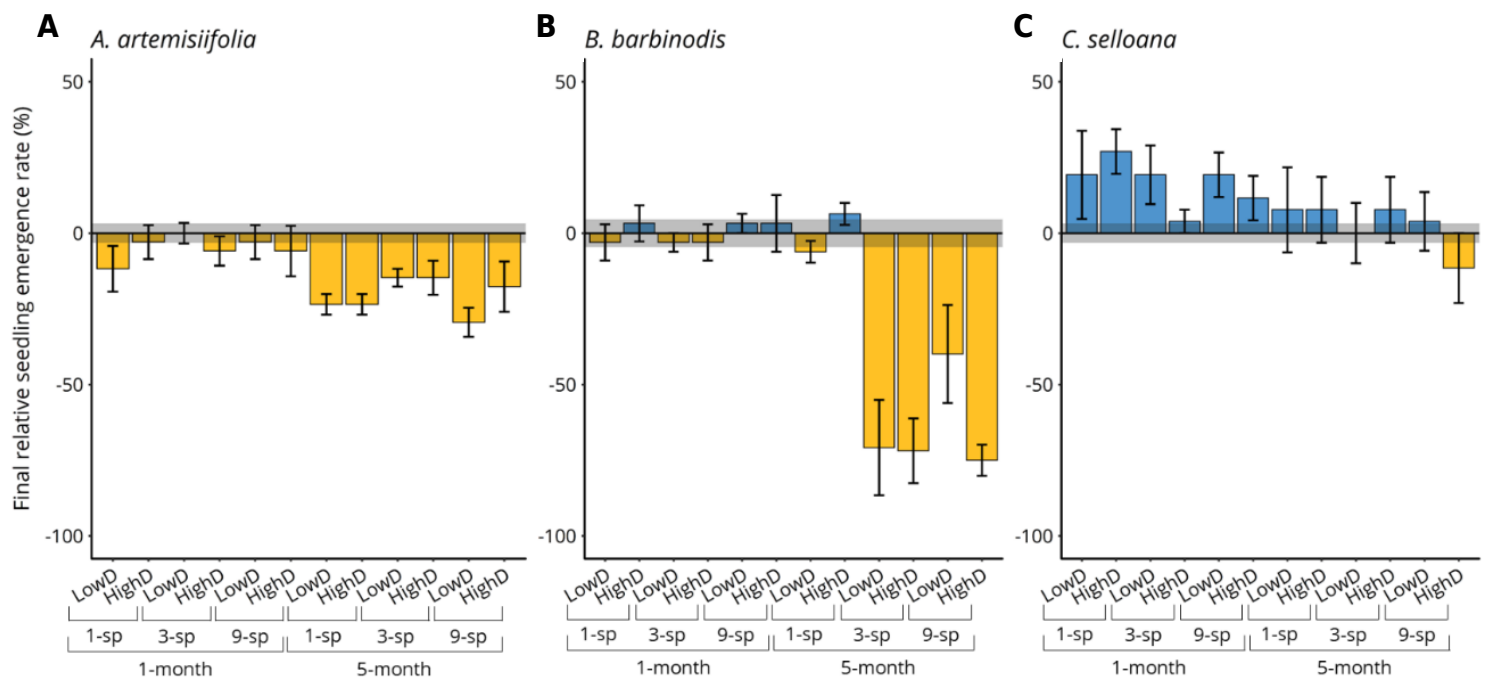

Figure S3.5 Final seedling emergence rate (mean $\pm S E, n=4)$ relative to the control $(0)$ of the invasive species (A) $A$. artemisiifolia, (B) B. barbinodis and (C) C. selloana, depending on recipient community type: time advance over invasive species (1- or 5-month), species composition (1-sp = 1 species, 3-sp = 3 species, 9 -sp $=9$ species), and density (LowD = low density or HighD = high density). Values below or above zero refer respectively to decreased or increased final seedling emergence rate compared to the control. SE of the control (bare soil) is represented by a grey area.
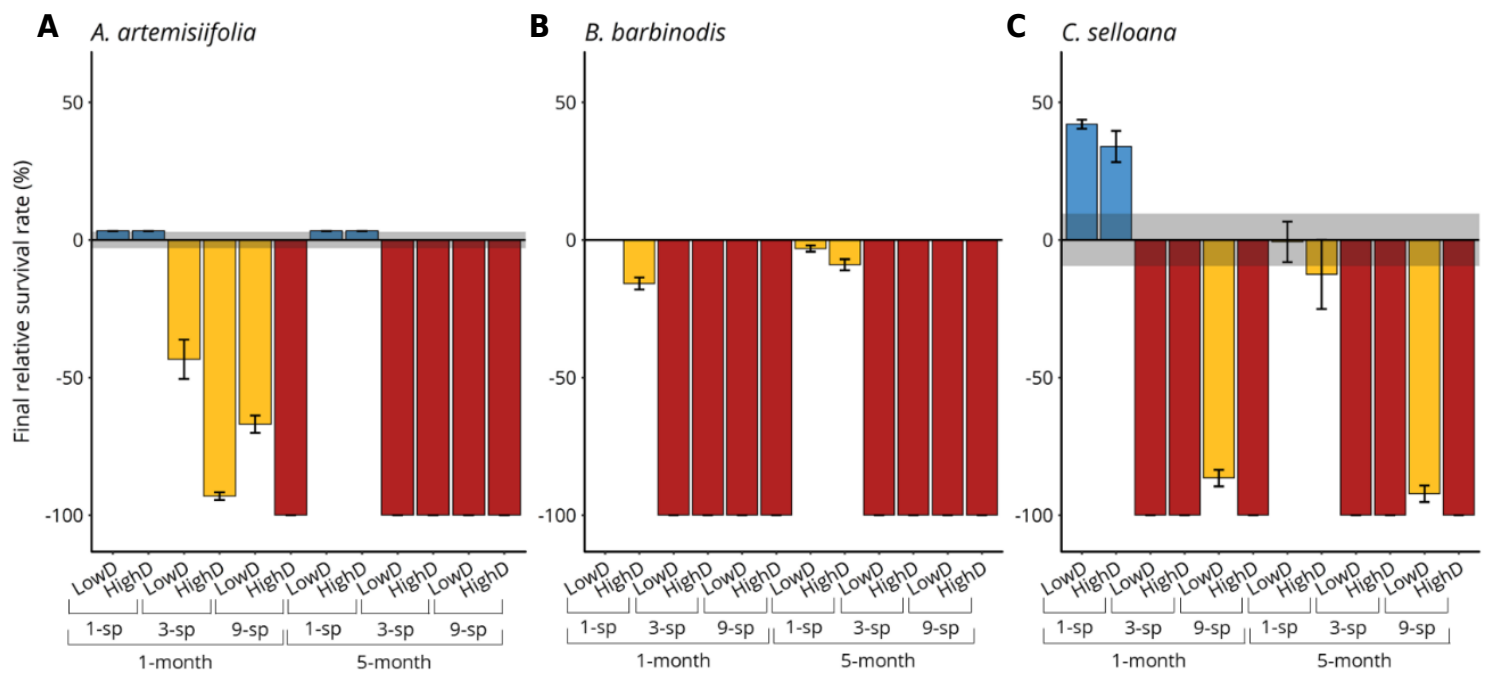

Figure S3.6 Final survival rate (mean $\pm \mathrm{SE}, \mathrm{n}=4$ ) relative to the control $(0)$ of the invasive species $(\mathbf{A}) A$. artemisiifolia, (B) $B$. barbinodis and (C) $C$. selloana, depending on recipient community type: time advance over invasive species (1- or 5-month), species composition (1-sp = 1 species, 3-sp = 3 species, $9-\mathrm{sp}=9$ species) and density (LowD = low density or HighD $=$ high density). Values below or above zero refer respectively to decreased or increased final germination rate compared to the control. Red bars indicate no survivors. SE of the control (bare soil) is represented by a grey area. 